Acta Crystallographica Section C

Structural Chemistry

ISSN 2053-2296

\title{
Different patterns of supramolecular assembly in constitutionally similar 6-arylimidazo[2,1-b][1,3,4]thiadiazoles
}

\section{Aletti S. Praveen, ${ }^{a}$ Hemmige S. Yathirajan, ${ }^{a}$ Manpreet Kaur, ${ }^{\mathrm{a}}$ Badiadka Narayana, ${ }^{\mathrm{b}}$ Eric C. Hosten, ${ }^{\mathrm{c}}$ Richard Betz $^{\mathrm{C}_{*}}$ and Christopher Glidewell ${ }^{\mathrm{d} *}$}

\footnotetext{
${ }^{a}$ Department of Studies in Chemistry, University of Mysore, Manasagangotri, Mysore 570 006, India, 'bepartment of Studies in Chemistry, Mangalore University, Mangalagangotri 574 199, India, 'Department of Chemistry, Nelson Mandela Metropolitan University, Summerstrand Campus (South), University Way, Summerstrand, PO Box 77000, Port Elizabeth, 6031, South Africa, and ${ }^{\mathbf{d}}$ School of Chemistry, University of St Andrews, Fife KY16 9ST, Scotland

Correspondence e-mail: richard.betz@nmmu.ac.za, cg@st-andrews.ac.uk
}

Received 18 August 2014

Accepted 18 August 2014

Four imidazo[2,1- $b][1,3,4]$ thiadiazoles containing a simplysubstituted 6-aryl group have been synthesized by reaction of 2-amino-1,3,4-thiadiazoles with bromoacetylarenes using microwave irradiation and brief reaction times. 6-(2-Chlorophenyl)imidazo[2,1-b][1,3,4]thiadiazole, $\mathrm{C}_{10} \mathrm{H}_{6} \mathrm{ClN}_{3} \mathrm{~S}, \quad$ (I), 6-(2-chlorophenyl)-2-methylimidazo[2,1-b][1,3,4]thiadiazole, $\mathrm{C}_{11} \mathrm{H}_{8} \mathrm{ClN}_{3} \mathrm{~S}$, (II), 6-(3,4-dichlorophenyl)imidazo[2,1-b][1,3,4]thiadiazole, $\mathrm{C}_{10} \mathrm{H}_{5} \mathrm{Cl}_{2} \mathrm{~N}_{3} \mathrm{~S}$, (III), and 6-(4-fluoro-3-methoxyphenyl)-2-methylimidazo[2,1- $b][1,3,4]$ thiadiazole, $\mathrm{C}_{12} \mathrm{H}_{10} \mathrm{FN}_{3^{-}}$ OS, (IV), crystallize with $Z^{\prime}$ values of $2,1,1$ and 2 respectively. The molecular skeletons are all nearly planar and the dihedral angles between the imidazole and aryl rings are 1.51 (8) and $7.28(8)^{\circ}$ in (I), $9.65(7)^{\circ}$ in (II), $10.44(8)^{\circ}$ in (III), and 1.05 (8) and $7.21(8)^{\circ}$ in (IV). The molecules in (I) are linked by three independent $\mathrm{C}-\mathrm{H} \cdots \mathrm{N}$ hydrogen bonds to form ribbons containing alternating $R_{2}^{2}(8)$ and $R_{4}^{4}(18)$ rings, and these ribbons are linked into a three-dimensional array by three independent $\pi$-stacking interactions. Both (II) and (III) contain centrosymmetric dimers formed by $\pi$-stacking interactions but hydrogen bonds are absent, and the molecules of (IV) are linked into centrosymmetric $R_{2}^{2}(8)$ dimers by C$\mathrm{H} \cdots \mathrm{N}$ hydrogen bonds. Comparisons are made with a number of related compounds.

Keywords: crystal structure; imidazo[2,1-b][1,3,4]thiadiazoles; molecular conformation; supramolecular assembly; pharmaceutical compounds; hydrogen bonding.

\section{Introduction}

Compounds containing the imidazo[2,1- $b][1,3,4]$ thiadiazole unit exhibit a wide range of biological activity, including antimicrobial (Ravi et al., 2009), antitubercular (Andanappa et al., 2004; Shankar et al., 2012) and anti-inflamatory (Jadhav et $a l ., 2008)$ activities. Imidazo[2,1-b][1,3,4]thiadiazole derivatives also act as cyclooxygenase inhibitors (Andanappa et al., 2008) and antihyperlipidemic agents (Jadhav et al., 2008). We report here the synthesis, molecular structures and supramolecular assembly of four related 6-arylimidazo[2,1- $b$ ]$[1,3,4]$ thiadiazoles, namely 6-(2-chlorophenyl)imidazo[2,1-b][1,3,4]thiadiazole, (I), 6-(2-chlorophenyl)-2-methylimidazo[2,1-b][1,3,4]thiadiazole, (II), 6-(3,4-dichlorophenyl)imidazo$[2,1-b][1,3,4]$ thiadiazole, (III), and 6-(4-fluoro-3-methoxyphenyl)-2-methylimidazo[2,1- $b][1,3,4]$ thiadiazole, (IV), which we compare with the related compounds (V)-(VIII) (see Scheme). The purposes of the present study are: (i) the comparison of the series of closely related molecular structures (I)-(IV); (ii) the exploration of the similarities and differences in their supramolecular assembly; (iii) the comparison of the structures of (I)-(IV) with the recently reported structures of some simple analogues, viz. compounds (V) (Praveen et al., 2013), (VI) (Fun, Hemamalini et al., 2011), (VII) (Fun, Yeap et al., 2011) and (VIII) (Banu et al., 2011) (see Scheme).
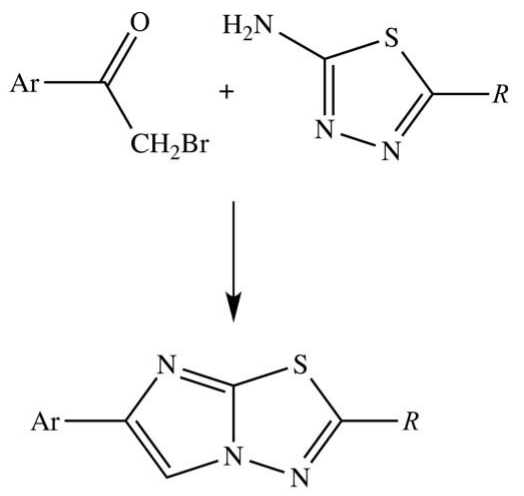

$$
\begin{array}{ll}
\text { (I) } & R=\mathrm{H}, \mathrm{Ar}=2-\mathrm{ClC}_{6} \mathrm{H}_{4} \\
\text { (II) } & R=\mathrm{Me}, \mathrm{Ar}=2-\mathrm{ClC}_{6} \mathrm{H}_{4} \\
\text { (III) } & R=\mathrm{H}, \mathrm{Ar}=3,4-\mathrm{Cl}_{2} \mathrm{C}_{6} \mathrm{H}_{3} \\
\text { (IV) } & R=\mathrm{Me}, \mathrm{Ar}=3-\mathrm{MeO}_{4}-\mathrm{FC}_{6} \mathrm{H}_{3} \\
\text { (V) } & R=\mathrm{H}, \mathrm{Ar}=3-\mathrm{ClC}_{6} \mathrm{H}_{4} \\
\text { (VI) } & R=\mathrm{Me}_{2} \mathrm{CHCH} 2, \mathrm{Ar}=\mathrm{Ph} \\
\text { (VII) } & R=\mathrm{Me}_{2} \mathrm{CHCH}_{2}, \mathrm{Ar}=4-\mathrm{MeOC}_{6} \mathrm{H}_{4} \\
\text { (VIII) } & R=4-\mathrm{FC}_{6} \mathrm{H}_{4} \mathrm{CH}_{2}, \mathrm{Ar}=4-\mathrm{BrC}_{6} \mathrm{H}_{4}
\end{array}
$$

\section{Experimental}

\subsection{Synthesis and crystallization}

For the synthesis of each of compounds (I)-(IV), a mixture of the appropriately substituted bromoacetylarene $(10 \mathrm{mmol})$ with either 2-amino-1,3,4-thiadiazole [for (I) and (III)] or 2-amino-5-methyl-1,3,4-thiadiazole [for (II) and (IV)] $(10 \mathrm{mmol})$ in $N, N$-dimethylformamide $(20 \mathrm{ml})$ was placed in a Pyrex glass tube and subjected to microwave irradiation at $373 \mathrm{~K}$ for $10 \mathrm{~min}$, using a Biotage Initiator-microwave reactor fitted with a rotating stage. The reaction mixtures were allowed to cool to ambient temperature and were then poured onto crushed ice. The resulting solid products were collected by filtration and dried in air. Colourless crystals suitable for 
Table 1

Experimental details.

\begin{tabular}{|c|c|c|c|c|}
\hline & (I) & (II) & (III) & (IV) \\
\hline \multicolumn{5}{|l|}{ Crystal data } \\
\hline Chemical formula & $\mathrm{C}_{10} \mathrm{H}_{6} \mathrm{ClN}_{3} \mathrm{~S}$ & $\mathrm{C}_{11} \mathrm{H}_{8} \mathrm{ClN}_{3} \mathrm{~S}$ & $\mathrm{C}_{10} \mathrm{H}_{5} \mathrm{Cl}_{2} \mathrm{~N}_{3} \mathrm{~S}$ & $\mathrm{C}_{12} \mathrm{H}_{10} \mathrm{FN}_{3} \mathrm{OS}$ \\
\hline$M_{\mathrm{r}}$ & 235.69 & 249.71 & 270.13 & 263.29 \\
\hline Crystal system, space group & Triclinic, $P \overline{1}$ & Orthorhombic, $\mathrm{Pbca}$ & Triclinic, $P \overline{1}$ & Triclinic, $P \overline{1}$ \\
\hline Temperature $(\mathrm{K})$ & 200 & 200 & 200 & 200 \\
\hline$a, b, c(\AA)$ & $\begin{array}{l}7.5805(4), 9.7942(5) \\
13.6175(6)\end{array}$ & $\begin{array}{l}7.5567(3), 11.4589(5) \\
24.9006(11)\end{array}$ & $\begin{array}{l}5.5186(2), 7.5194(3) \\
\quad 12.8406(5)\end{array}$ & $\begin{array}{l}8.6766(3), 11.7888(4), \\
12.5227(4)\end{array}$ \\
\hline$\alpha, \beta, \gamma\left({ }^{\circ}\right)$ & $\begin{array}{l}97.712(2), 96.549(2) \\
\quad 99.416(2)\end{array}$ & $90,90,90$ & $\begin{array}{l}102.027(2), 91.293(2) \\
\quad 98.430(2)\end{array}$ & $\begin{array}{l}103.039(2), 95.189(2), \\
110.365(2)\end{array}$ \\
\hline$V\left(\AA^{3}\right)$ & $978.77(8)$ & $2156.18(16)$ & $514.74(3)$ & $1149.69(7)$ \\
\hline$Z$ & 4 & 8 & 2 & 4 \\
\hline Radiation type & Mo $K \alpha$ & Mo $K \alpha$ & Mo $K \alpha$ & Mo $K \alpha$ \\
\hline$\mu\left(\mathrm{mm}^{-1}\right)$ & 0.57 & 0.52 & 0.80 & 0.29 \\
\hline Crystal size (mm) & $0.39 \times 0.37 \times 0.29$ & $0.59 \times 0.47 \times 0.27$ & $0.39 \times 0.38 \times 0.30$ & $0.51 \times 0.49 \times 0.16$ \\
\hline \multicolumn{5}{|l|}{ Data collection } \\
\hline Diffractometer & $\begin{array}{l}\text { Bruker APEXII CCD } \\
\text { diffractometer }\end{array}$ & $\begin{array}{l}\text { Bruker APEXII CCD } \\
\text { diffractometer }\end{array}$ & $\begin{array}{l}\text { Bruker APEXII CCD } \\
\text { diffractometer }\end{array}$ & $\begin{array}{l}\text { Bruker APEXII CCD } \\
\text { diffractometer }\end{array}$ \\
\hline Absorption correction & $\begin{array}{l}\text { Multi-scan }(S A D A B S \\
\quad \text { Sheldrick, 2003) }\end{array}$ & $\begin{array}{l}\text { Multi-scan }(S A D A B S \\
\quad \text { Sheldrick, 2003) }\end{array}$ & $\begin{array}{l}\text { Multi-scan }(S A D A B S \\
\quad \text { Sheldrick, 2003) }\end{array}$ & $\begin{array}{l}\text { Multi-scan }(S A D A B S \\
\quad \text { Sheldrick, 2003) }\end{array}$ \\
\hline$T_{\min }, T_{\max }$ & $0.779,0.851$ & $0.773,0.870$ & $0.747,0.794$ & $0.761,0.957$ \\
\hline $\begin{array}{l}\text { No. of measured, independent and observed } \\
\quad[I>2 \sigma(I)] \text { reflections }\end{array}$ & $16930,4729,4168$ & $15450,2666,2356$ & $12326,2453,2254$ & $19758,5695,4829$ \\
\hline$R_{\text {int }}$ & 0.026 & 0.015 & 0.017 & 0.019 \\
\hline$(\sin \theta / \lambda)_{\max }\left(\AA^{-1}\right)$ & 0.668 & 0.667 & 0.667 & 0.668 \\
\hline \multicolumn{5}{|l|}{ Refinement } \\
\hline$R\left[F^{2}>2 \sigma\left(F^{2}\right)\right], w R\left(F^{2}\right), S$ & $0.032,0.094,1.03$ & $0.032,0.086,1.06$ & $0.027,0.071,1.12$ & $0.036,0.105,1.05$ \\
\hline No. of reflections & 4729 & 2666 & 2453 & 5695 \\
\hline No. of parameters & 271 & 146 & 145 & 329 \\
\hline H-atom treatment & $\begin{array}{l}\text { H-atom parameters } \\
\text { constrained }\end{array}$ & $\begin{array}{l}\text { H-atom parameters } \\
\text { constrained }\end{array}$ & $\begin{array}{l}\text { H-atom parameters } \\
\text { constrained }\end{array}$ & $\begin{array}{l}\text { H-atom parameters } \\
\text { constrained }\end{array}$ \\
\hline$\Delta \rho_{\max }, \Delta \rho_{\min }\left(\mathrm{e} \AA^{-3}\right)$ & $0.40,-0.32$ & $0.31,-0.42$ & $0.36,-0.33$ & $0.38,-0.24$ \\
\hline
\end{tabular}

Computer programs: APEX2 (Bruker, 2010), SAINT (Bruker, 2010), SHELXS97 (Sheldrick, 2008), SHELXL2014 (Sheldrick, 2014) and PLATON (Spek, 2009).

single-crystal X-ray diffraction were grown by slow evaporation, at ambient temperature and in the presence of air, of solutions in ethyl acetate. Data for compound (I): yield 69\%, m.p. 448-450 K; ${ }^{1} \mathrm{H}$ NMR [dimethyl sulfoxide (DMSO)- $d_{6}$ ]: $\delta 7.33(m, 1 \mathrm{H}$, aryl $), 7.42(m, 1 \mathrm{H}$, aryl $), 7.53(d, J=7.92 \mathrm{~Hz}, 1 \mathrm{H}$, aryl), $8.11(d, J=7.60 \mathrm{~Hz}, 1 \mathrm{H}$, aryl $), 8.60(s, 1 \mathrm{H}$, imidazole $)$, $9.27\left(s, 1 \mathrm{H}\right.$, thiadiazole); MS: $236(M+1)^{+}$for $\mathrm{C}_{10} \mathrm{H}_{6}{ }^{35} \mathrm{ClN}_{3} \mathrm{~S}$. Data for compound (II): yield 63\%, m.p. 398-400 K; ${ }^{1} \mathrm{H}$ NMR (DMSO- $\left.d_{6}\right): \delta 2.73(s, 3 \mathrm{H}$, methyl), $7.31(\mathrm{~m}, 1 \mathrm{H}$, aryl), $7.41(\mathrm{~m}$, $1 \mathrm{H}$, aryl $), 7.52(d, J=7.80 \mathrm{~Hz}, 1 \mathrm{H}$, aryl $), 8.09(d, J=7.84 \mathrm{~Hz}$, $1 \mathrm{H}$, aryl $), 8.71(s, 1 \mathrm{H}$, imidazole $)$; MS: $249=(M+1)^{+}$for $\mathrm{C}_{11} \mathrm{H}_{8}{ }^{35} \mathrm{ClN}_{3} \mathrm{~S}$. Data for compound (III): yield 75\%, m.p. 418$419 \mathrm{~K} ;{ }^{1} \mathrm{H}$ NMR (DMSO- $\left.d_{6}\right): \delta 7.66(d, J=8.40 \mathrm{~Hz}, 1 \mathrm{H}$, aryl), $7.84(d, J=8.40 \mathrm{~Hz}, 1 \mathrm{H}$, aryl $), 8.09(s, 1 \mathrm{H}$, aryl $), 8.86(s, 1 \mathrm{H}$, imidazole); MS: $271(M+2)^{+}$for $\mathrm{C}_{10} \mathrm{H}_{5}{ }^{35} \mathrm{Cl}_{2} \mathrm{~N}_{3} \mathrm{~S}$. Data for compound (IV): yield 76\%, m.p. $375-378 \mathrm{~K}$; ${ }^{1} \mathrm{H}$ NMR (DMSO- $\left.d_{6}\right): \delta 2.73$ ( $s, 3 \mathrm{H}$, methyl), 3.90 ( $s, 3 \mathrm{H}$, methoxy), 7.24 ( $m, 1 \mathrm{H}$, aryl), $7.42(m, 1 \mathrm{H}$, aryl $), 7.62(m, 1 \mathrm{H}$, aryl $), 8.64(s, 1 \mathrm{H}$, imidazole); MS: $264(M+1)^{+}$for $\mathrm{C}_{12} \mathrm{H}_{10} \mathrm{FN}_{3} \mathrm{OS}$.

\subsection{Refinement}

Crystal data, data collection and structure refinement details are summarized in Table 1 . All $\mathrm{H}$ atoms were located in difference maps and then treated as riding atoms, with $\mathrm{C}-\mathrm{H}=$ 0.95 (aryl and heterocyclic) or $0.98 \AA$ (methyl) and with $U_{\text {iso }}(\mathrm{H})=k U_{\text {eq }}(\mathrm{C})$, where $k=1.5$ for the methyl groups, which were permitted to rotate but not to tilt, and 1.2 for all other $\mathrm{H}$ atoms. For compound (IV), two low-angle reflections, viz. 101 and $\overline{1} 11$, which had been attenuated by the beam stop, were omitted from the final refinements. Examination of the refined structures using PLATON (Spek, 2009) showed that none of them contained any solvent-accessible voids.

\section{Results and discussion}

The compounds reported here were all prepared using a cyclocondensation reaction between 2-amino-1,3,4-thiadiazole and a bromoacetylarene mediated by microwave irradiation (cf. Scheme). Exactly the same type of microwave-induced reaction had been used in the preparation of compound $(\mathrm{V})$. The same type of cyclocondensation was used in the syntheses of compounds (VI)-(VIII) but, instead of using microwave irradiation, the reaction mixtures were heated under reflux in ethanol solutions, for periods of $4 \mathrm{~h}$ for each of (VI) and (VII) and of $18 \mathrm{~h}$ for (VIII). Unfortunately, no yields were reported for compounds (VI)-(VIII), but the extended reaction times used in their preparations certainly point to the efficacy of the microvave-induced syntheses for compounds (I)-(V).

The crystallization characteristics of compounds (I)-(IV) (Figs. 1-4) show some interesting and unexpected features. Although the molecular constitutions of compounds (I) and (II) differ only in the presence of a methyl group in (II) which 


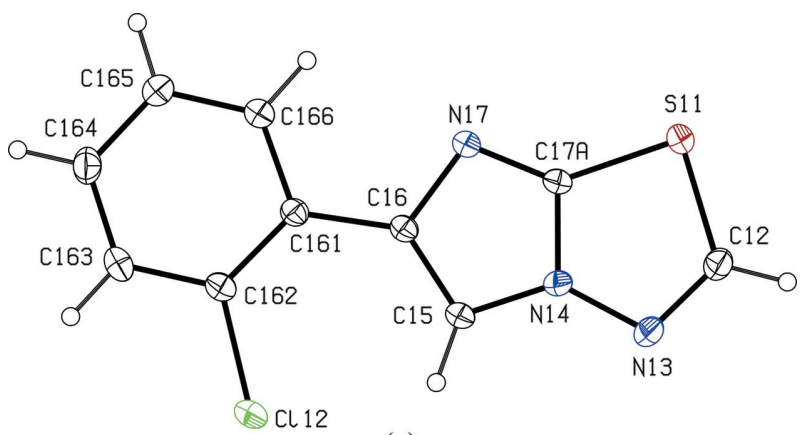

(a)

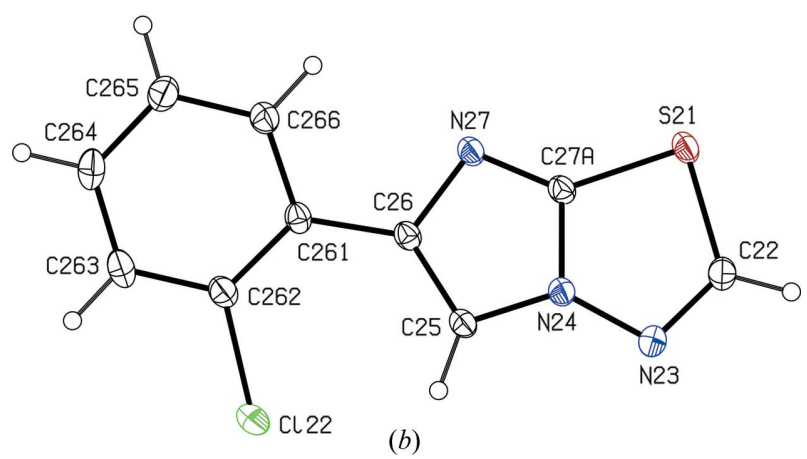

Figure 1

The structures of the two independent molecules in compound (I), showing the atom-labelling scheme for $(a)$ a type 1 molecule and $(b)$ a type 2 molecule. Displacement ellipsoids are drawn at the $30 \%$ probability level.

is absent from (I), compound (I) crystallizes in the space group $P \overline{1}$ with $Z^{\prime}=2$, while compound (II) crystallizes in the space group $P b c a$ with $Z^{\prime}=1$. Again, the constitutions of compounds (I) and (III) differ only in the number and locations of the chloro substituents in the aryl ring, but these compounds, although crystallizing in the same space group, do so with $Z^{\prime}$ values of 2 and 1 , respectively. Compound (IV) also crystallizes with $Z^{\prime}=2$. By contrast, compound $(\mathrm{V})$, which differs from (I) only in the location of the single chloro substituent, crystallizes in the monoclinic space group $P 2_{1} / n$ with $Z^{\prime}=1$ (Praveen et al., 2013). Hence, no two of the simple chloroaryl derivatives (I)-(III) and (V) are isomorphous. For compounds (I) and (IV), it will be convenient to refer to the molecules containing atoms S11 and S21 (Figs. 1 and 4) as types 1 and 2, respectively.

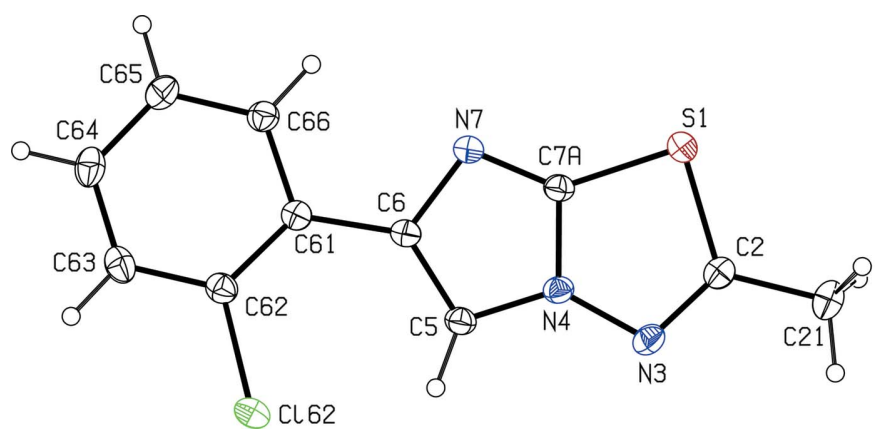

Figure 2

The molecular structure of compound (II), showing the atom-labelling scheme. Displacement ellipsoids are drawn at the $30 \%$ probability level.

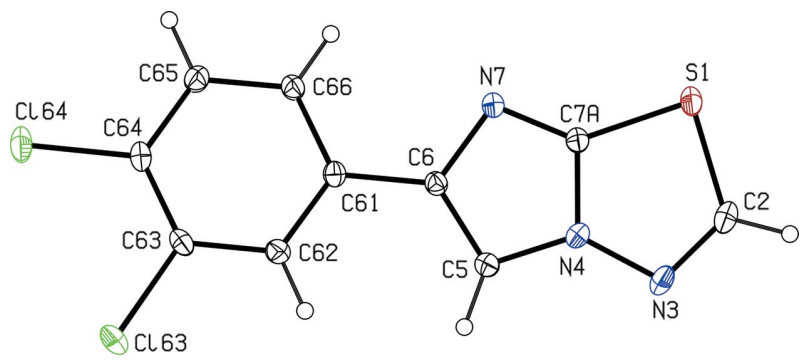

Figure 3

The molecular structure of compound (III), showing the atom-labelling scheme. Displacement ellipsoids are drawn at the $30 \%$ probability level.

The bond distances in the molecules of compounds (I)-(IV) (Table 2) present some interesting patterns. The bond S $x 1-$ $\mathrm{C} x 2$ (where $x=1,2$ or nil; see Table 2 for definitions) is consistently longer than $\mathrm{S} x 1-\mathrm{C} x 7 A$, regardless of whether or not there is a methyl substituent at atom $\mathrm{C} x 2$; the $\mathrm{C} x 2-\mathrm{N} x 3$ bond is always the shortest $\mathrm{C}-\mathrm{N}$ bond in the molecule, and it may be regarded as a fully localized double bond. Of the four independent $\mathrm{N}-\mathrm{C}$ bonds in the imidazole ring, $\mathrm{N} x 7-\mathrm{C} x 7 A$ is always significantly shorter than the other three such bonds, which have fairly similar lengths, suggesting a considerable degree of bond fixation in this ring. On the other hand, in each of compounds (I)-(III) there are close intermolecular contacts

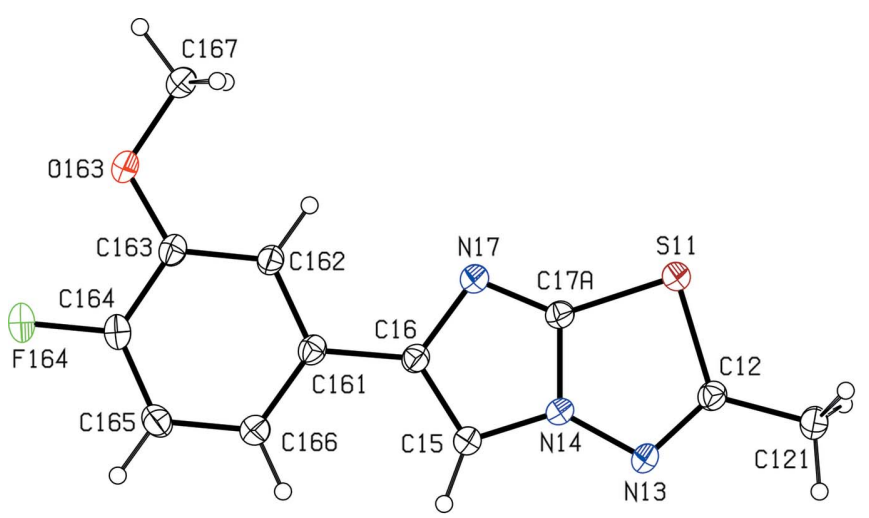

(a)

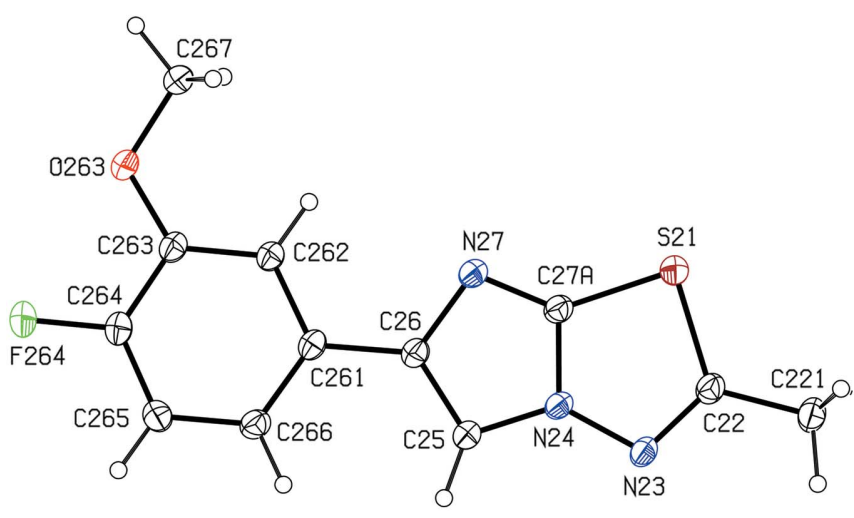

(b)

Figure 4

The structures of the two independent molecules in compound (IV), showing the atom-labelling scheme for $(a)$ a type 1 molecule and $(b)$ a type 2 molecule. Displacement ellipsoids are drawn at the $30 \%$ probability level. 
Table 2

Selected geometric parameters $\left(\AA,^{\circ}\right)$ for compounds (I)-(IV).

\begin{tabular}{|c|c|c|c|c|c|c|}
\hline Parameter & $\begin{array}{l}(\mathrm{I}), \text { molecule } 1 \\
(x=1)\end{array}$ & $\begin{array}{l}(\mathrm{I}), \text { molecule } 2 \\
(x=2)\end{array}$ & $\begin{array}{l}(\mathrm{II}) \\
(x=\mathrm{nil})\end{array}$ & $\begin{array}{l}(\mathrm{III}) \\
(x=\mathrm{nil})\end{array}$ & $\begin{array}{l}\text { (IV), molecule } 1 \\
(x=1)\end{array}$ & $\begin{array}{l}\text { (IV), molecule } 2 \\
(x=2)\end{array}$ \\
\hline $\mathrm{S} x 1-\mathrm{C} x 2$ & $1.7441(16)$ & $1.7504(16)$ & $1.7491(15)$ & $1.7419(16)$ & $1.7605(14)$ & $1.7531(15)$ \\
\hline $\mathrm{C} x 2-\mathrm{N} x 3$ & $1.288(2)$ & $1.290(2)$ & 1.2937 (19) & $1.288(2)$ & $1.2970(18)$ & $1.3004(19)$ \\
\hline $\mathrm{N} x 3-\mathrm{N} x 4$ & $1.3703(17)$ & $1.3717(17)$ & $1.3731(16)$ & $1.3730(16)$ & $1.3717(15)$ & $1.3708(15)$ \\
\hline $\mathrm{N} x 4-\mathrm{C} x 5$ & $1.3693(19)$ & $1.3742(18)$ & $1.3686(17)$ & $1.3706(18)$ & $1.3687(17)$ & $1.3693(18)$ \\
\hline $\mathrm{C} x 5-\mathrm{C} x 6$ & $1.379(2)$ & $1.378(2)$ & 1.3777 (19) & $1.3787(18)$ & $1.3740(19)$ & $1.3759(18)$ \\
\hline $\mathrm{C} x 6-\mathrm{N} x 7$ & $1.3997(18)$ & $1.4018(17)$ & $1.3957(17)$ & $1.3918(17)$ & $1.3978(17)$ & $1.3940(18)$ \\
\hline $\mathrm{N} x 7-\mathrm{C} x 7 A$ & $1.3093(18)$ & 1.3087 (19) & $1.3082(17)$ & $1.3105(17)$ & $1.3075(18)$ & $1.3111(17)$ \\
\hline $\mathrm{C} x 7 A-\mathrm{S} x 1$ & $1.7287(15)$ & $1.7333(14)$ & $1.7283(14)$ & $1.7310(14)$ & $1.7297(14)$ & $1.7307(15)$ \\
\hline $\mathrm{N} x 4-\mathrm{C} x 7 A$ & $1.3594(18)$ & $1.3575(18)$ & $1.3583(17)$ & $1.3683(18)$ & $1.3678(18)$ & $1.3651(18)$ \\
\hline $\mathrm{C} x 63-\mathrm{O} x 63-\mathrm{C} x 67$ & & & & & $116.49(11)$ & $116.68(11)$ \\
\hline $\mathrm{C} x 62-\mathrm{C} x 63-\mathrm{O} x 63$ & & & & & $125.54(13)$ & $125.73(13)$ \\
\hline $\mathrm{C} x 64-\mathrm{C} x 63-\mathrm{O} x 63$ & & & & & $116.19(12)$ & $116.04(12)$ \\
\hline $\mathrm{C} x 62-\mathrm{C} x 63-\mathrm{O} x 63-\mathrm{C} x 67$ & & & & & $-3.5(2)$ & $-10.5(2)$ \\
\hline Aryl/imidazole & $1.51(8)$ & $7.28(8)$ & $9.65(7)$ & $10.44(8)$ & $1.05(8)$ & $7.21(8)$ \\
\hline
\end{tabular}

between inversion-related pairs of imidazole rings, as discussed in detail below, and these contacts are strongly suggestive of a $\pi-\pi$ stacking interaction in each case. A similar contact is present in the structure of $(\mathrm{V})$.

The molecular skeletons in compounds (I)-(IV) are all close to planarity, as shown by the very small dihedral angles (Table 2) between the planes of the aryl and imidazole rings. The corresponding dihedral angles in compounds (V), (VII) and (VIII) are also small [6.24 (11), 4.63 (7) and $8.62(18)^{\circ}$, respectively], although that in compound (VI) is rather larger $\left[24.36(7)^{\circ}\right]$. In compound (IV), the torsion angles $\mathrm{C} x 62-$ Cx63-Ox63-Cx67 (Table 2) show that the $\mathrm{C}$ atom of the methoxy group is close to the plane of the adjacent aryl ring; the displacements of atoms C167 and C267 from the planes of the $\mathrm{C} 161-\mathrm{C} 166$ and $\mathrm{C} 261-\mathrm{C} 266$ rings are 0.054 (2) and 0.231 (2) $\AA$, respectively. Consistent with this, the two exocyclic $\mathrm{C}-\mathrm{C}-\mathrm{O}$ angles in each of the independent molecules of (IV) differ by almost $10^{\circ}$, as is typically found in planar methoxyaryl systems (Seip \& Seip, 1973; Ferguson et al., 1996). The $\mathrm{C}-\mathrm{O}-\mathrm{C}$ angles are both significantly larger than the near-tetrahedral value of $111.5(15)^{\circ}$ observed in dimethyl ether (Kimura \& Kubo, 1959). Entirely comparable $\mathrm{C}-\mathrm{C}-\mathrm{O}$ and $\mathrm{C}-\mathrm{O}-\mathrm{C}$ angles are found in the structure of compound (VII), although this was not mentioned in the original structure report (Fun, Yeap et al., 2011).

Although compound (I) has the simplest molecular constitution amongst the compounds reported here, it exhibits the

\section{Table 3}

Hydrogen bonds and short intramolecular contacts $\left(\AA{ }^{\circ}\right)$ for compounds (I)-(IV).

$\mathrm{Cg} 1$ represents the centroid of the C61-C66 ring.

\begin{tabular}{llllll}
\hline Compound & $D-\mathrm{H} \cdots A$ & $D-\mathrm{H}$ & $\mathrm{H} \cdots A$ & $D \cdots A$ & $D-\mathrm{H} \cdots A$ \\
\hline (I) & $\mathrm{C} 12-\mathrm{H} 12 \cdots \mathrm{N} 27$ & 0.95 & 2.33 & $3.280(2)$ & 178 \\
& $\mathrm{C} 25-\mathrm{H} 25 \cdots \mathrm{N} 23^{\mathrm{i}}$ & 0.95 & 2.61 & $3.480(2)$ & 153 \\
& $\mathrm{C} 263-\mathrm{H} 263 \cdots \mathrm{N} 13^{\mathrm{ii}}$ & 0.95 & 2.51 & $3.456(2)$ & 179 \\
(II) & $\mathrm{C} 64-\mathrm{H} 64 \cdots \mathrm{Cg} 1^{\mathrm{iii}}$ & 0.95 & 2.90 & $3.6297(16)$ & 135 \\
(IV) & $\mathrm{C} 15-\mathrm{H} 15 \cdots \mathrm{N} 13^{\mathrm{ii}}$ & 0.95 & 2.61 & $3.551(2)$ & 169 \\
\hline
\end{tabular}

Symmetry codes: (i) $-x,-y+2,-z+1$; (ii) $-x+1,-y+1,-z+1$; (iii) $x-\frac{1}{2}, y,-z+\frac{3}{2}$. most elaborate supramolecular assembly, involving both hydrogen bonds (Table 3 ) and close $\pi-\pi$ interactions involving the imidazole rings. Two further $\mathrm{C}-\mathrm{H} \cdots \mathrm{N}$ hydrogen bonds link the molecules into a ribbon running parallel to the [1 $\overline{1} 0]$ direction and containing two types of centrosymmetric ring, in which $R_{2}^{2}(8)$ (Bernstein et al., 1995) rings built from type 2 molecules only and centred at $\left(n, 1-n, \frac{1}{2}\right)$ alternate with $R_{4}^{4}(18)$ rings containing both types of molecule and centred at $\left(\frac{1}{2}+n, \frac{1}{2}-n, \frac{1}{2}\right)$, where $n$ represents an integer in each case (Fig. 5). Only one of these ribbons passes through each unit cell, but adjacent ribbons are linked by three independent $\pi-\pi$ stacking interactions to form a three-dimensional array, whose formation can be analysed easily in terms of simple substructures (Ferguson et al., 1998a,b; Gregson et al., 2000).

Two of these interactions, involving only the type $1 \mathrm{~mol}-$ ecules, link the ribbons into sheets. The imidazole rings of the
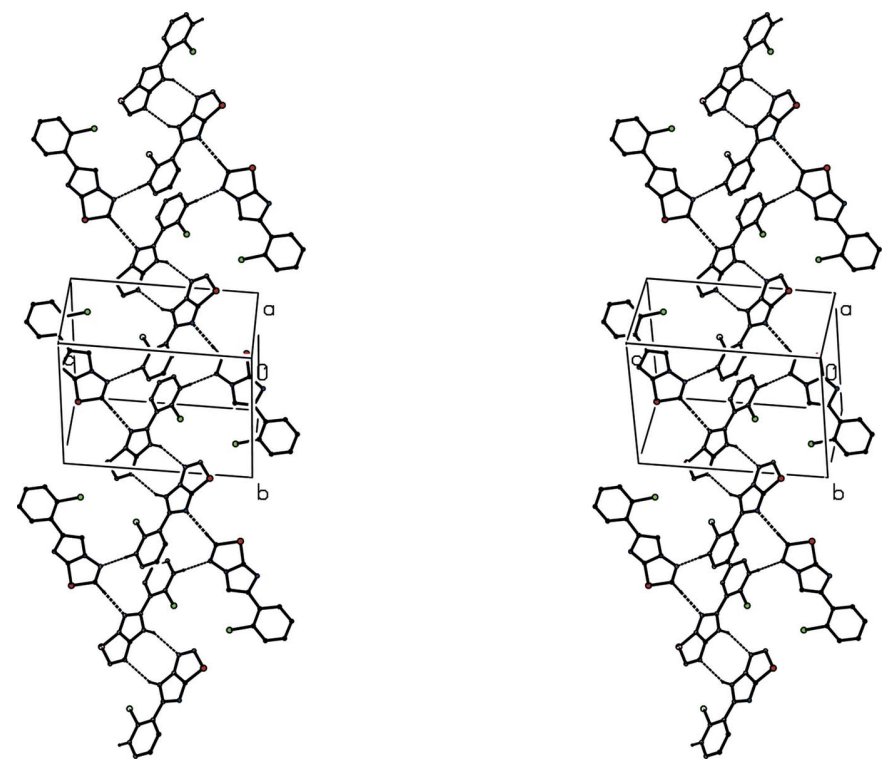

Figure 5

A stereoview of part of the crystal structure of compound (I), showing the formation of a ribbon of hydrogen-bonded $R_{2}^{2}(8)$ and $R_{4}^{4}(18)$ rings running parallel to the [1ํㅣㄹ direction. Hydrogen bonds are shown as dashed lines and, for the sake of clarity, $\mathrm{H}$ atoms not involved in the motifs shown have been omitted. 

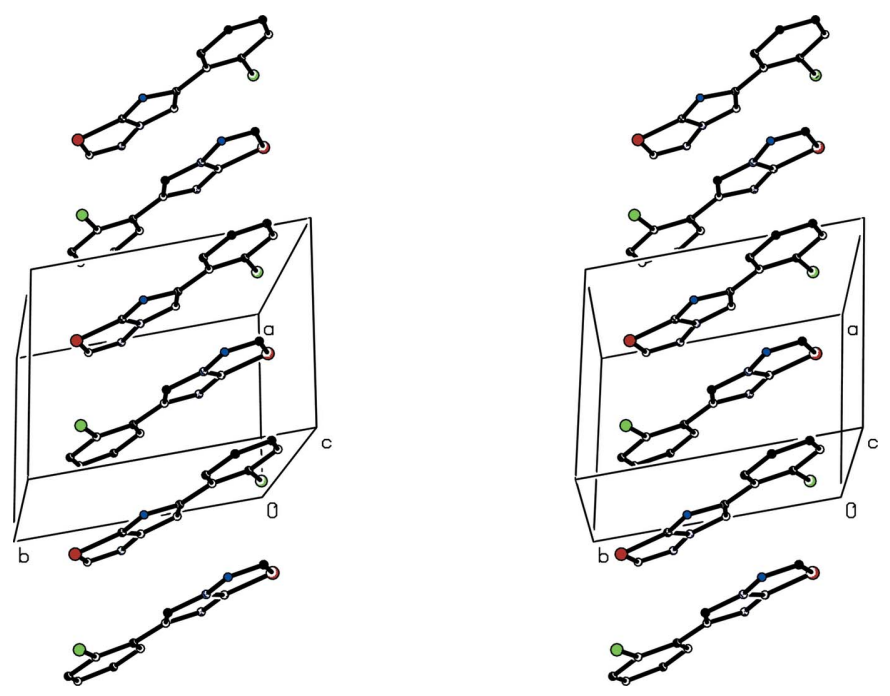

Figure 6

A stereoview of part of the crystal structure of compound (I), showing the formation of a $\pi$-stacked chain of type 1 molecules running parallel to the [100] direction and built from type 1 molecules only. For the sake of clarity, all $\mathrm{H}$ atoms have been omitted.

type 1 molecules at $(x, y, z)$ and $(-x+1,-y+1,-z+2)$ are parallel, with an interplanar spacing of 3.4770 (6) $\AA$ and a ring-centroid separation of 3.6542 (9) $\AA$, corresponding to a ring-centroid offset of $1.124 \AA$. The imidazole ring of the type 1 molecule at $(x, y, z)$ makes a dihedral angle of only $1.51(8)^{\circ}$ with the aryl ring of the type 1 molecule at $(-x+2,-y+1$, $-z+2$ ); the ring-centroid separation is 3.7460 (9) $\AA$ and the shortest perpendicular distances from the centroid of one ring to the plane of the other is 3.4542 (7) $\AA$, corresponding to a ring-centroid offset of $c a 1.45 \AA$. The combination of these

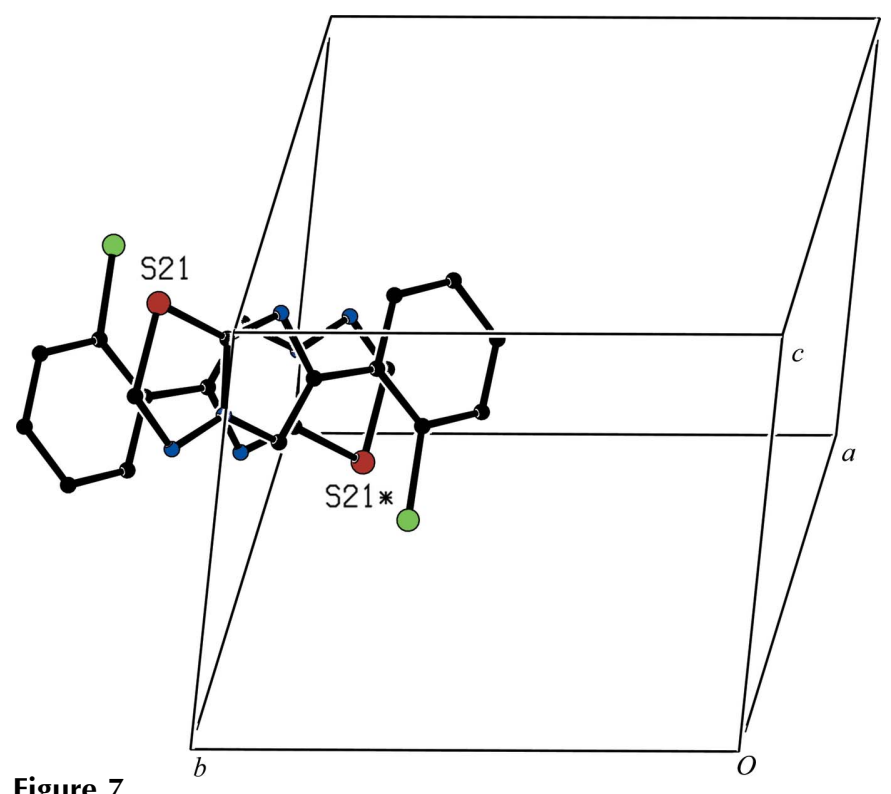

Figure 7

Part of the crystal structure of compound (I), showing the formation of a centrosymmetric $\pi$-stacked dimer centred at $\left(\frac{1}{2}, 1, \frac{1}{2}\right)$ which links the $(001)$ sheets. For the sake of clarity, all $\mathrm{H}$ atoms have been omitted and atoms marked with an asterisk $\left(^{*}\right)$ are at the symmetry position $(-x+1,-y+2$, $-z+1)$.

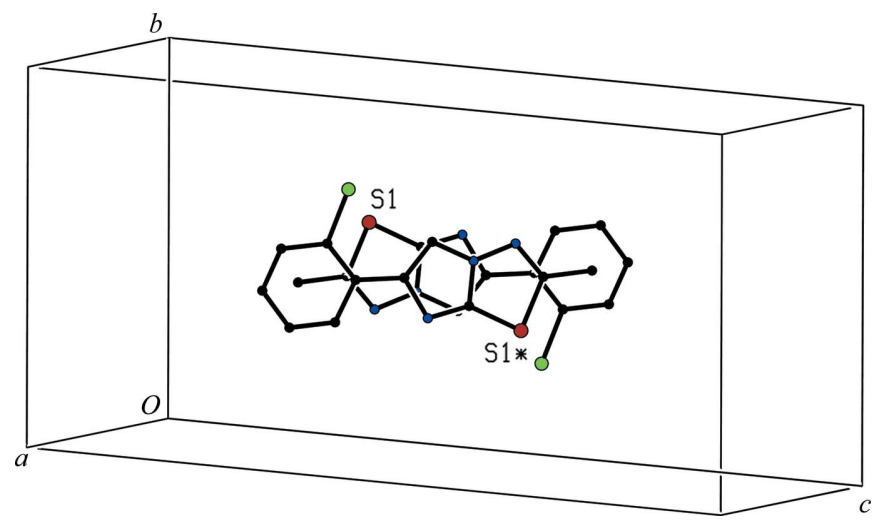

Figure 8

Part of the crystal structure of compound (II), showing the formation of a centrosymmetric $\pi$-stacked dimer centred at $\left(\frac{1}{2}, \frac{1}{2}, \frac{1}{2}\right)$. For the sake of clarity, all $\mathrm{H}$ atoms have been omitted and the $\mathrm{S}$ atom marked with an asterisk $(*)$ is at the symmetry position $(-x+1,-y+1,-z+1)$.

two stacking interactions generates a chain running parallel to the [100] direction (Fig. 6) which links the hydrogen-bonded ribbons to form a sheet lying parallel to (001). The third $\pi$-stacking interaction involves only type 2 molecules. The imidazole ring of the type 2 molecule at $(x, y, z)$ makes a dihedral angle of $7.28(8)^{\circ}$ with the aryl ring of the type 2 molecule at $(-x+1,-y+2,-z+1)$; the ring-centroid separation is 3.7159 (9) $\AA$ and the shortest perpendicular distances from the centroid of one ring to the plane of the other is 3.3905 (7) $\AA$, corresponding to a ring-centroid offset of $c a 1.52 \AA$ (Fig. 7). The effect of this final $\pi$-stacking interaction is to link adjacent (001) sheets, so forming a threedimensional structure.

The supramolecular assembly in compounds (II) and (III) is very much simpler than that in compound (I). The structure of (II) contains one short intermolecular $\mathrm{C}-\mathrm{H} \cdots \pi$ (arene) contact (Table 3), but the $\mathrm{H} \cdots \mathrm{Cg}$ and $\mathrm{C} \cdots \mathrm{Cg}$ distances are both quite long and the $\mathrm{C}-\mathrm{H} \cdots \mathrm{Cg}$ angle is less than $140^{\circ}$ so that this contact is probably not structurally significant ( $c f$. Wood et al., 2009), while there are no hydrogen bonds of any kind in the structure of (III). In both structures, there is a single $\pi$-stacking interaction between inversion-related pairs

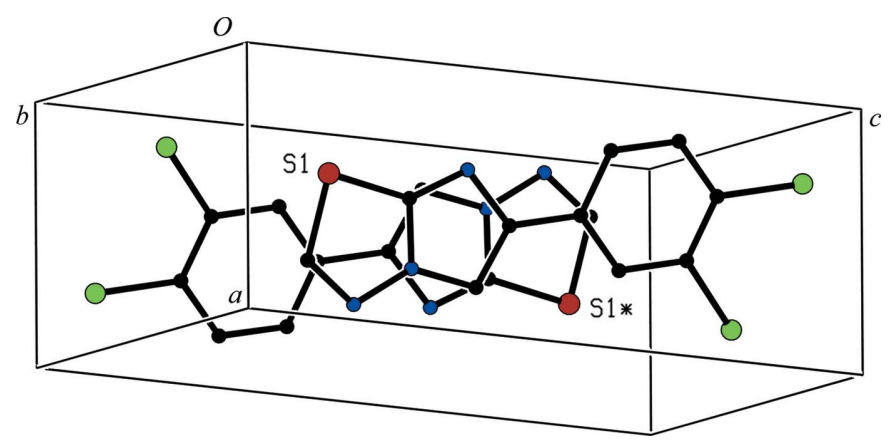

Figure 9

Part of the crystal structure of compound (III), showing the formation of a centrosymmetric $\pi$-stacked dimer centred at $\left(\frac{1}{2}, \frac{1}{2}, \frac{1}{2}\right)$. For the sake of clarity, all $\mathrm{H}$ atoms have been omitted and the $\mathrm{S}$ atom marked with an asterisk $(*)$ is at the symmetry position $(-x+1,-y+1,-z+1)$. 


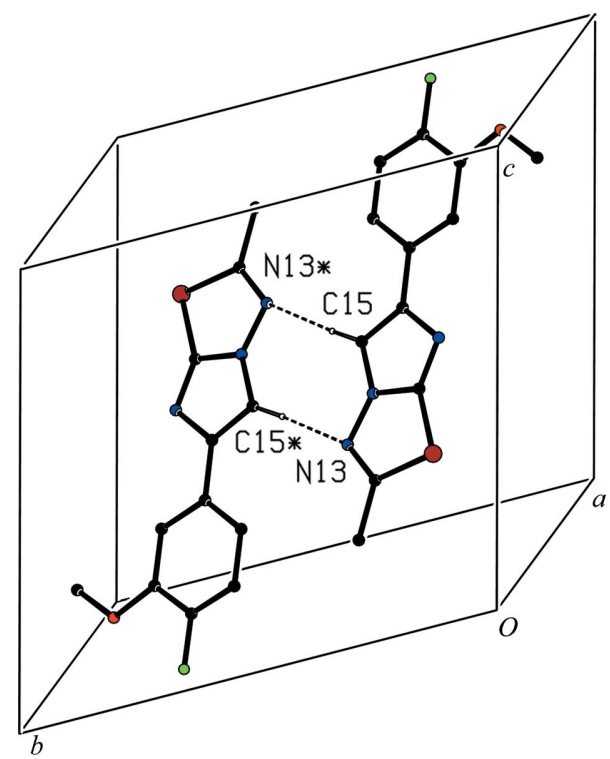

Figure 10

Part of the crystal structure of compound (IV), showing the formation of a centrosymmetric hydrogen-bonded $R_{2}^{2}(8)$ dimer centred at $\left(\frac{1}{2}, \frac{1}{2}, \frac{1}{2}\right)$. For the sake of clarity, $\mathrm{H}$ atoms not involved in the motif shown have been omitted and atoms marked with an asterisk (*) are at the symmetry position $(-x+1,-y+1,-z+1)$.

of imidazole rings forming centrosymmetric dimers, centred in each case at $\left(\frac{1}{2}, \frac{1}{2}, \frac{1}{2}\right)$ (Figs. 8 and 9). In (II), the interplanar spacing is 3.4635 (6) $\AA$, the ring-centroid separation is 3.6112 (8) $\AA$ and the ring-centroid offset is $1.022 \AA$; in (III), these values are $3.5296(6) \AA$, $3.6696(8)^{\circ}$ and $1.004 \AA$, respectively.

In the structure of compound (IV), inversion-related pairs of type 1 molecules are linked by symmetry-related $\mathrm{C}-\mathrm{H} \cdots \mathrm{N}$ hydrogen bonds (Table 3 ) to form a cyclic centrosymmetric dimer characterized by an $R_{2}^{2}(8)$ motif (Fig. 10). The only other short intermolecular contacts involve $\mathrm{C}-\mathrm{H}$ bonds in methyl groups. However, when groups of approximate local $C_{2}$ and $C_{3}$ symmetry are linked by a single bond, as here, the barrier to rotation about the linking bond is very low, only a few $\mathrm{J} \mathrm{mol}^{-1}$ (Tannenbaum et al., 1956; Naylor \& Wilson, 1957), and in such circumstances hydrocarbyl substituents generally undergo very rapid rotation around the bond linking them to the adjacent planar unit, even in the solid state (Riddell \& Rogerson, 1996, 1997). Hence such contacts cannot be regarded as structurally significant. In addition to the $\mathrm{C}-$ $\mathrm{H} \cdots \mathrm{N}$ hydrogen bond which generates a dimer of type 1 molecules, there is a further fairly short intermolecular contact, this time between the two molecules within the selected asymmetric unit. The planes of the imidazole rings of these two molecules make a dihedral angle of only $5.712(9)^{\circ}$, but the ring-centroid separation is long [3.9051 (10) $\AA$ ]. The shortest perpendicular distance from the centroid of one ring to the plane of the other is quite short [3.4074 (7) $\AA$ ], corresponding to a ring-centroid offset of $1.91 \AA$, which is probably too long for this contact to be regarded as structurally significant.
The supramolecular assembly in compounds (I)-(IV) reported here may be compared with that in compounds (V)(VIII) (see Scheme). In compound (V) (Praveen et al., 2013), there are no hydrogen bonds of any kind, but inversionrelated pairs of molecules are linked by a $\pi$-stacking interaction involving the imidazole rings, exactly comparable to compounds (II) and (III), but in the structure of compound (VI) (Fun, Hemamalini et al., 2011) there are neither hydrogen bonds nor $\pi$-stacking interactions. The supramolecular assembly in compound (VII) (Fun, Yeap et al., 2011 ) is more complex than that of (V) or (VI). Inversionrelated pairs of molecules are linked into centrosymmetric dimers by symmetry-related pairs of $\mathrm{C}-\mathrm{H} \cdots \pi$ (arene) hydrogen bonds and these dimers are linked by an aromatic $\pi-\pi$ stacking interaction involving inversion-related pairs of aryl rings, so forming a chain of $\pi$-stacked hydrogen-bonded dimers running parallel to the [010] direction (Fig. 11), although this chain formation was not described in the original structure report. Finally, in compound (VIII (Banu et al., 2011), molecules related by a $2_{1}$ screw axis are linked by a $\mathrm{C}-$ $\mathrm{H} \cdots \mathrm{N}$ hydrogen bond to form a $C(6)$ chain running parallel to the [010] direction.

Thus, across the entire series of compounds (I)-(VIII), rather similar molecular constitutions are associated with a wide variety of supramolecular assembly patterns, ranging from isolated molecules in compound (VI), via $\pi$-stacked dimers in compounds (II), (III) and (V) and hydrogen-bonded dimers in compound (IV), to simple hydrogen-bonded chains in compound (VIII) and chains of $\pi$-stacked hydrogenbonded dimers in compound (VII), to a three-dimensional array of $\pi$-stacked hydrogen-bonded ribbons in compound (I).
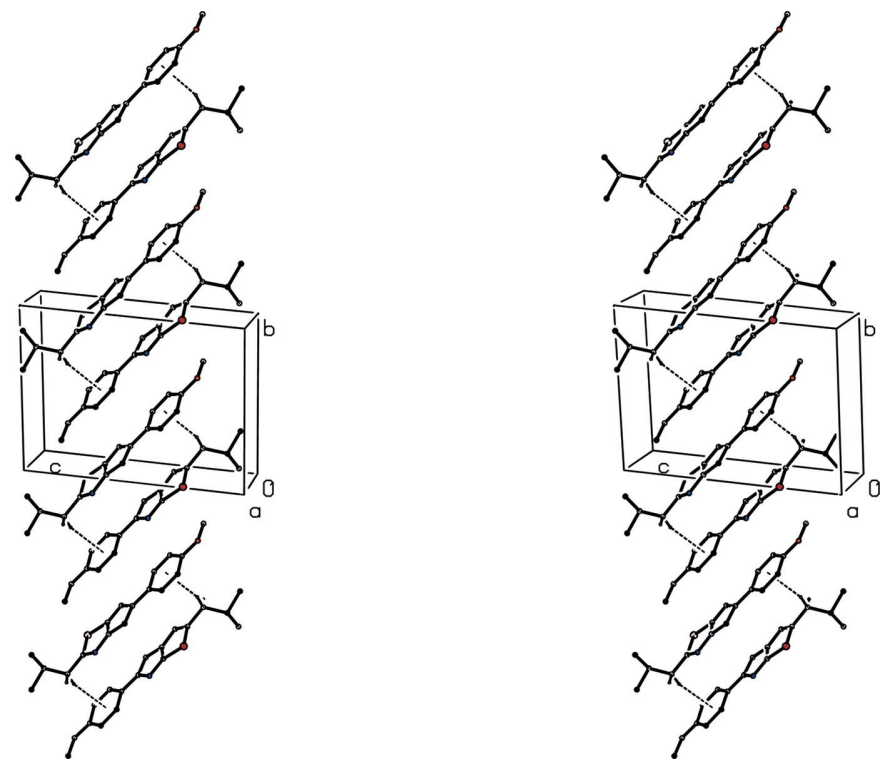

Figure 11

A stereoview of part of the crystal structure of compound (VII), showing the formation of a $\pi$-stacked chain of hydrogen-bonded dimers running parallel to the [010] direction. The original atomic coordinates (Fun, Yeap et al., 2011) have been used. Hydrogen bonds are shown as dashed lines and, for the sake of clarity, $\mathrm{H}$ atoms bonded to $\mathrm{C}$ atoms which are not involved in the motif shown have been omitted. 
ASP is grateful to the University of Mysore for the provision of research facilities.

\section{References}

Andanappa, K. G., Mahesh, B. P., Anand, K., Malleshappa, N. N., Thippeswamy, S. B. \& Wagwade, J. (2008). Bioorg. Med. Chem. 16, 276-283. Andanappa, K. G., Malleshappa, N. N. \& Rajshekhar, V. K. (2004). Bioorg. Med. Chem. 12, 5651-5659.

Banu, A., Begum, N. S., Lamani, R. S. \& Khazi, I. M. (2011). Acta Cryst. E67, 0779.

Bernstein, J., Davis, R. E., Shimoni, L. \& Chang, N.-L. (1995). Angew. Chem. Int. Ed. Engl. 34, 1555-1573.

Bruker (2010). APEX2, SAINT and $S A D A B S$. Bruker AXS Inc., Madison, Wisconsin, USA.

Ferguson, G., Glidewell, C., Gregson, R. M. \& Meehan, P. R. (1998a). Acta Cryst. B54, 129-138.

Ferguson, G., Glidewell, C., Gregson, R. M. \& Meehan, P. R. (1998b). Acta Cryst. B54, 139-150.

Ferguson, G., Glidewell, C. \& Patterson, I. L. J. (1996). Acta Cryst. C52, 420423.

Fun, H.-K., Hemamalini, M., Prasad, D. J., Castelino, P. A. \& Anitha, V. V. (2011). Acta Cryst. E67, o254.
Fun, H.-K., Yeap, C. S., Prasad, D. J., Castelino, P. A. \& Anitha, V. V. (2011). Acta Cryst. E67, o255.

Gregson, R. M., Glidewell, C., Ferguson, G. \& Lough, A. J. (2000). Acta Cryst. B56, 39-57.

Jadhav, V. B., Kulkarni, M. V., Rasal, V. P., Biradar, S. S. \& Vinay, M. D. (2008). Eur. J. Med. Chem. 43, 1721-1729.

Kimura, K. \& Kubo, M. (1959). J. Chem. Phys. 30, 151-158.

Naylor, R. E. \& Wilson, E. B. (1957). J. Chem. Phys. 26, 1057-1060.

Praveen, A. S., Jasinski, J. P., Krauss, S. T., Yathirajan, H. S. \& Narayana, B. (2013). Acta Cryst. E69, o66.

Ravi, S. L., Nitinkumar, S. S., Ravindra, R. K. \& Imtiyaz, A. M. K. (2009). Eur. J. Med. Chem. 44, 2828-2833.

Riddell, F. G. \& Rogerson, M. (1996). J. Chem. Soc. Perkin Trans. 2, pp. 493 504.

Riddell, F. G. \& Rogerson, M. (1997). J. Chem. Soc. Perkin Trans. 2, pp. 249256.

Seip, H. M. \& Seip, R. (1973). Acta Chem. Scand. 27, 4024-4027.

Shankar, G. A., Kallanagouda, R. A., Pranali, V. S., Sagar, M. C., Dilip, H. D. \& Amol, S. S. (2012). Bioorg. Med. Chem. Lett. 22, 1917-1921.

Sheldrick, G. M. (2003). SADABS. University of Göttingen, Germany.

Sheldrick, G. M. (2008). Acta Cryst. A64, 112-122.

Sheldrick, G. M. (2014). SHELXL2014. University of Göttingen, Germany.

Spek, A. L. (2009). Acta Cryst. D65, 148-155.

Tannenbaum, E., Myers, R. J. \& Gwinn,W. D. (1956). J. Chem. Phys. 25, 42-47.

Wood, P. A., Allen, F. H. \& Pidcock, E. (2009). CrystEngComm, 11, 1563-1571. 


\title{
supporting information
}

Acta Cryst. (2014). C70, 920-926 [doi:10.1107/S2053229614018762]

\section{Different patterns of supramolecular assembly in constitutionally similar 6-aryl- imidazo[2,1-b][1,3,4]thiadiazoles}

\author{
Aletti S. Praveen, Hemmige S. Yathirajan, Manpreet Kaur, Badiadka Narayana, Eric C. Hosten, \\ Richard Betz and Christopher Glidewell
}

\section{Computing details}

For all compounds, data collection: APEX2 (Bruker, 2010); cell refinement: SAINT (Bruker, 2010); data reduction: SAINT (Bruker, 2010); program(s) used to solve structure: SHELXS97 (Sheldrick, 2008); program(s) used to refine structure: SHELXL2014 (Sheldrick, 2014); molecular graphics: PLATON (Spek, 2009). Software used to prepare material for publication: SHELXL2014 (Sheldrick, 2014) and PLATON (Spek, 2009) for (I), (III); SHELXL2014 (Sheldrick, 2014 and PLATON (Spek, 2009) for (II); SHELXL2014 (Sheldrick, 2014) and PLATON(Spek, 2009 for (IV).

(I) 6-(2-Chlorophenyl)imidazo[2,1-b][1,3,4] thiadiazole

Crystal data

$\mathrm{C}_{10} \mathrm{H}_{6} \mathrm{ClN}_{3} \mathrm{~S}$

$M_{r}=235.69$

Triclinic, $P \overline{1}$

$a=7.5805(4) \AA$

$b=9.7942(5) \AA$

$c=13.6175(6) \AA$

$\alpha=97.712(2)^{\circ}$

$\beta=96.549(2)^{\circ}$

$\gamma=99.416(2)^{\circ}$

$V=978.77(8) \AA^{3}$

Data collection

Bruker APEXII CCD

diffractometer

Radiation source: fine-focus sealed tube

$\varphi$ and $\omega$ scans

Absorption correction: multi-scan

(SADABS; Sheldrick, 2003)

$T_{\min }=0.779, T_{\max }=0.851$

16930 measured reflections

Refinement

Refinement on $F^{2}$

Least-squares matrix: full

$R\left[F^{2}>2 \sigma\left(F^{2}\right)\right]=0.032$

$w R\left(F^{2}\right)=0.094$

$S=1.03$

4729 reflections
$Z=4$

$F(000)=480$

$D_{\mathrm{x}}=1.599 \mathrm{Mg} \mathrm{m}^{-3}$

Mo $K \alpha$ radiation, $\lambda=0.71073 \AA$

Cell parameters from 4729 reflections

$\theta=1.5-28.3^{\circ}$

$\mu=0.57 \mathrm{~mm}^{-1}$

$T=200 \mathrm{~K}$

Block, colourless

$0.39 \times 0.37 \times 0.29 \mathrm{~mm}$

4729 independent reflections

4168 reflections with $I>2 \sigma(I)$

$R_{\text {int }}=0.026$

$\theta_{\max }=28.3^{\circ}, \theta_{\min }=1.5^{\circ}$

$h=-7 \rightarrow 10$

$k=-12 \rightarrow 12$

$l=-14 \rightarrow 18$

271 parameters

0 restraints

Hydrogen site location: inferred from neighbouring sites

$\mathrm{H}$-atom parameters constrained 
$w=1 /\left[\sigma^{2}\left(F_{\mathrm{o}}^{2}\right)+(0.0516 P)^{2}+0.4007 P\right]$

where $P=\left(F_{\mathrm{o}}^{2}+2 F_{\mathrm{c}}^{2}\right) / 3$

$(\Delta / \sigma)_{\max }=0.001$

$$
\Delta \rho_{\max }=0.40 \text { e } \AA^{-3}
$$

$\Delta \rho_{\min }=-0.32$ e $\AA^{-3}$

\section{Special details}

Geometry. All e.s.d.'s (except the e.s.d. in the dihedral angle between two 1.s. planes) are estimated using the full covariance matrix. The cell e.s.d.'s are taken into account individually in the estimation of e.s.d.'s in distances, angles and torsion angles; correlations between e.s.d.'s in cell parameters are only used when they are defined by crystal symmetry. An approximate (isotropic) treatment of cell e.s.d.'s is used for estimating e.s.d.'s involving l.s. planes.

Fractional atomic coordinates and isotropic or equivalent isotropic displacement parameters $\left(\hat{A}^{2}\right)$

\begin{tabular}{|c|c|c|c|c|}
\hline & $x$ & $y$ & $z$ & $U_{\text {iso }} * / U_{\text {eq }}$ \\
\hline $\mathrm{S} 11$ & $0.63036(5)$ & $0.83031(4)$ & $0.95902(3)$ & $0.03096(10)$ \\
\hline $\mathrm{C} 12$ & $0.6159(2)$ & $0.77634(17)$ & $0.83053(12)$ & $0.0321(3)$ \\
\hline H12 & 0.5851 & 0.8354 & 0.7838 & $0.039^{*}$ \\
\hline N13 & $0.64851(19)$ & 0.65344 (14) & $0.80129(9)$ & $0.0324(3)$ \\
\hline N14 & $0.68820(17)$ & $0.59455(13)$ & $0.88501(9)$ & $0.0257(3)$ \\
\hline $\mathrm{C} 15$ & $0.7354(2)$ & $0.46903(15)$ & $0.89990(11)$ & $0.0274(3)$ \\
\hline H15 & 0.7490 & 0.3944 & 0.8507 & $0.033^{*}$ \\
\hline $\mathrm{C} 16$ & $0.75892(18)$ & $0.47526(14)$ & $1.00245(10)$ & $0.0234(3)$ \\
\hline N17 & $0.72793(17)$ & $0.60324(12)$ & $1.05002(9)$ & $0.0261(3)$ \\
\hline C17A & $0.68590(19)$ & $0.67001(14)$ & $0.97609(10)$ & $0.0244(3)$ \\
\hline $\mathrm{C} 161$ & $0.81017(18)$ & $0.37360(14)$ & $1.06587(10)$ & $0.0240(3)$ \\
\hline $\mathrm{C} 162$ & $0.84856(19)$ & $0.24170(15)$ & $1.03223(11)$ & $0.0265(3)$ \\
\hline $\mathrm{Cl12}$ & $0.82721(6)$ & $0.17517(4)$ & $0.90520(3)$ & $0.03711(11)$ \\
\hline $\mathrm{C} 163$ & $0.9007(2)$ & $0.15413(16)$ & $1.09785(13)$ & $0.0312(3)$ \\
\hline H163 & 0.9274 & 0.0658 & 1.0725 & $0.037 *$ \\
\hline C164 & $0.9139(2)$ & $0.19499(17)$ & $1.19985(13)$ & $0.0363(4)$ \\
\hline H164 & 0.9511 & 0.1358 & 1.2450 & $0.044 *$ \\
\hline $\mathrm{C} 165$ & $0.8722(3)$ & 0.32295 (19) & $1.23553(13)$ & $0.0400(4)$ \\
\hline H165 & 0.8784 & 0.3512 & 1.3055 & $0.048^{*}$ \\
\hline C166 & $0.8218(2)$ & $0.40998(17)$ & $1.16984(12)$ & $0.0342(3)$ \\
\hline H166 & 0.7939 & 0.4976 & 1.1960 & $0.041 *$ \\
\hline $\mathrm{S} 21$ & $0.36631(5)$ & $1.18560(4)$ & $0.79107(3)$ & $0.03005(10)$ \\
\hline $\mathrm{C} 22$ & $0.1501(2)$ & $1.18596(16)$ & $0.73233(11)$ & $0.0296(3)$ \\
\hline $\mathrm{H} 22$ & 0.0765 & 1.2461 & 0.7606 & $0.036^{*}$ \\
\hline $\mathrm{N} 23$ & $0.09280(17)$ & $1.10206(14)$ & $0.64925(10)$ & $0.0305(3)$ \\
\hline N24 & $0.22771(16)$ & $1.02941(13)$ & $0.62857(9)$ & $0.0248(2)$ \\
\hline $\mathrm{C} 25$ & $0.2429(2)$ & $0.92574(15)$ & $0.55299(10)$ & $0.0265(3)$ \\
\hline $\mathrm{H} 25$ & 0.1572 & 0.8854 & 0.4958 & $0.032 *$ \\
\hline $\mathrm{C} 26$ & $0.41060(19)$ & $0.89356(14)$ & $0.57898(10)$ & $0.0237(3)$ \\
\hline $\mathrm{N} 27$ & $0.49777(17)$ & $0.97618(13)$ & $0.66889(9)$ & $0.0265(3)$ \\
\hline $\mathrm{C} 27 \mathrm{~A}$ & $0.38205(19)$ & $1.05534(15)$ & $0.69457(10)$ & $0.0248(3)$ \\
\hline $\mathrm{C} 261$ & $0.5077(2)$ & $0.79204(15)$ & $0.52924(10)$ & $0.0248(3)$ \\
\hline $\mathrm{C} 262$ & $0.4367(2)$ & $0.69015(16)$ & $0.44566(11)$ & $0.0293(3)$ \\
\hline $\mathrm{Cl} 22$ & $0.21459(6)$ & $0.67224(5)$ & $0.38873(4)$ & $0.04887(14)$ \\
\hline $\mathrm{C} 263$ & $0.5365(2)$ & $0.59638(17)$ & $0.40445(12)$ & $0.0355(3)$ \\
\hline H263 & 0.4838 & 0.5282 & 0.3479 & $0.043 *$ \\
\hline
\end{tabular}


supporting information

\begin{tabular}{lllll}
$\mathrm{C} 264$ & $0.7127(2)$ & $0.60240(18)$ & $0.44583(13)$ & $0.0373(4)$ \\
$\mathrm{H} 264$ & 0.7819 & 0.5384 & 0.4179 & $0.045^{*}$ \\
$\mathrm{C} 265$ & $0.7884(2)$ & $0.70205(18)$ & $0.52824(13)$ & $0.0358(3)$ \\
$\mathrm{H} 265$ & 0.9098 & 0.7065 & 0.5570 & $0.043^{*}$ \\
$\mathrm{C} 266$ & $0.6875(2)$ & $0.79502(16)$ & $0.56860(11)$ & $0.0302(3)$ \\
$\mathrm{H} 266$ & 0.7416 & 0.8632 & 0.6249 & $0.036^{*}$ \\
\hline
\end{tabular}

Atomic displacement parameters $\left(\AA^{2}\right)$

\begin{tabular}{|c|c|c|c|c|c|c|}
\hline & $U^{11}$ & $U^{22}$ & $U^{33}$ & $U^{12}$ & $U^{13}$ & $U^{23}$ \\
\hline S11 & $0.0410(2)$ & $0.02360(18)$ & $0.02883(19)$ & $0.01038(15)$ & $0.00159(15)$ & $0.00342(14)$ \\
\hline $\mathrm{C} 12$ & $0.0367(8)$ & $0.0318(8)$ & $0.0274(7)$ & $0.0064(6)$ & $-0.0010(6)$ & $0.0076(6)$ \\
\hline N13 & $0.0414(7)$ & $0.0316(7)$ & $0.0231(6)$ & $0.0065(5)$ & $-0.0017(5)$ & $0.0054(5)$ \\
\hline N14 & $0.0317(6)$ & $0.0238(6)$ & $0.0198(5)$ & $0.0038(5)$ & $0.0007(5)$ & 0.0009 (4) \\
\hline $\mathrm{C} 15$ & $0.0350(7)$ & $0.0208(6)$ & $0.0249(7)$ & $0.0052(5)$ & $0.0030(6)$ & $-0.0007(5)$ \\
\hline $\mathrm{C} 16$ & $0.0237(6)$ & $0.0202(6)$ & $0.0250(6)$ & $0.0029(5)$ & $0.0028(5)$ & $0.0010(5)$ \\
\hline N17 & $0.0327(6)$ & $0.0221(6)$ & $0.0234(6)$ & $0.0066(5)$ & $0.0036(5)$ & $0.0015(5)$ \\
\hline C17A & $0.0277(7)$ & $0.0214(6)$ & $0.0226(6)$ & $0.0042(5)$ & $0.0025(5)$ & $-0.0009(5)$ \\
\hline C161 & $0.0242(6)$ & $0.0213(6)$ & $0.0254(7)$ & $0.0024(5)$ & $0.0027(5)$ & $0.0023(5)$ \\
\hline C162 & $0.0257(6)$ & $0.0233(7)$ & $0.0293(7)$ & $0.0032(5)$ & $0.0052(5)$ & $0.0010(5)$ \\
\hline $\mathrm{Cl12}$ & $0.0531(2)$ & 0.02745 (19) & $0.0321(2)$ & $0.01368(16)$ & $0.00953(17)$ & $-0.00129(15)$ \\
\hline C163 & $0.0302(7)$ & $0.0229(7)$ & $0.0409(8)$ & $0.0067(5)$ & $0.0041(6)$ & $0.0049(6)$ \\
\hline C164 & $0.0419(9)$ & $0.0303(8)$ & $0.0387(9)$ & $0.0086(7)$ & $0.0025(7)$ & $0.0127(7)$ \\
\hline C165 & $0.0588(11)$ & $0.0348(9)$ & $0.0273(8)$ & $0.0123(8)$ & $0.0027(7)$ & $0.0056(7)$ \\
\hline C166 & $0.0485(9)$ & $0.0262(7)$ & $0.0281(7)$ & $0.0105(6)$ & $0.0041(7)$ & $0.0019(6)$ \\
\hline $\mathrm{S} 21$ & $0.0380(2)$ & 0.02969 (19) & $0.02121(17)$ & $0.01047(15)$ & $0.00104(14)$ & $-0.00321(14)$ \\
\hline $\mathrm{C} 22$ & $0.0337(7)$ & $0.0287(7)$ & $0.0281(7)$ & $0.0105(6)$ & $0.0064(6)$ & $0.0026(6)$ \\
\hline $\mathrm{N} 23$ & $0.0296(6)$ & $0.0319(7)$ & $0.0305(6)$ & $0.0111(5)$ & $0.0040(5)$ & $0.0006(5)$ \\
\hline $\mathrm{N} 24$ & $0.0273(6)$ & $0.0255(6)$ & $0.0218(5)$ & $0.0077(5)$ & $0.0022(5)$ & $0.0015(5)$ \\
\hline $\mathrm{C} 25$ & $0.0302(7)$ & $0.0264(7)$ & $0.0213(6)$ & $0.0064(5)$ & $0.0003(5)$ & $-0.0013(5)$ \\
\hline $\mathrm{C} 26$ & $0.0300(7)$ & $0.0221(6)$ & $0.0187(6)$ & $0.0054(5)$ & $0.0021(5)$ & $0.0029(5)$ \\
\hline $\mathrm{N} 27$ & $0.0318(6)$ & $0.0265(6)$ & $0.0206(5)$ & $0.0092(5)$ & $0.0002(5)$ & $-0.0003(5)$ \\
\hline C27A & $0.0303(7)$ & $0.0248(7)$ & $0.0189(6)$ & $0.0066(5)$ & $0.0007(5)$ & $0.0019(5)$ \\
\hline C261 & $0.0324(7)$ & $0.0226(6)$ & $0.0206(6)$ & $0.0072(5)$ & $0.0051(5)$ & $0.0036(5)$ \\
\hline C262 & $0.0367(8)$ & $0.0263(7)$ & $0.0240(7)$ & $0.0074(6)$ & $0.0007(6)$ & $0.0010(5)$ \\
\hline $\mathrm{Cl} 22$ & $0.0461(2)$ & $0.0448(2)$ & $0.0458(2)$ & $0.01490(19)$ & $-0.01480(19)$ & -0.01819 (19) \\
\hline C263 & $0.0499(9)$ & $0.0288(8)$ & $0.0278(7)$ & $0.0107(7)$ & $0.0075(7)$ & $-0.0019(6)$ \\
\hline C264 & $0.0483(9)$ & $0.0355(9)$ & $0.0340(8)$ & $0.0186(7)$ & $0.0159(7)$ & $0.0042(7)$ \\
\hline $\mathrm{C} 265$ & $0.0353(8)$ & $0.0403(9)$ & $0.0353(8)$ & $0.0150(7)$ & $0.0079(7)$ & $0.0055(7)$ \\
\hline C266 & $0.0335(7)$ & 0.0318 (8) & $0.0252(7)$ & $0.0086(6)$ & $0.0037(6)$ & $0.0013(6)$ \\
\hline
\end{tabular}

Geometric parameters $\left(\AA,{ }^{\circ}\right)$

\begin{tabular}{llll}
\hline $\mathrm{S} 11-\mathrm{C} 17 \mathrm{~A}$ & $1.7287(15)$ & $\mathrm{S} 21-\mathrm{C} 27 \mathrm{~A}$ & $1.7333(14)$ \\
$\mathrm{S} 11-\mathrm{C} 12$ & $1.7441(16)$ & $\mathrm{S} 21-\mathrm{C} 22$ & $1.7405(16)$ \\
$\mathrm{C} 12-\mathrm{N} 13$ & $1.288(2)$ & $\mathrm{C} 22-\mathrm{N} 23$ & $1.290(2)$ \\
$\mathrm{C} 12-\mathrm{H} 12$ & 0.9500 & $\mathrm{C} 22-\mathrm{H} 22$ & 0.9500 \\
$\mathrm{~N} 13-\mathrm{N} 14$ & $1.3703(17)$ & $\mathrm{N} 23-\mathrm{N} 24$ & $1.3717(17)$
\end{tabular}




\begin{tabular}{|c|c|c|c|}
\hline $\mathrm{N} 14-\mathrm{C} 17 \mathrm{~A}$ & $1.3594(18)$ & $\mathrm{N} 24-\mathrm{C} 27 \mathrm{~A}$ & $1.3575(18)$ \\
\hline $\mathrm{N} 14-\mathrm{C} 15$ & $1.3693(19)$ & $\mathrm{N} 24-\mathrm{C} 25$ & $1.3742(18)$ \\
\hline $\mathrm{C} 15-\mathrm{C} 16$ & $1.379(2)$ & $\mathrm{C} 25-\mathrm{C} 26$ & $1.378(2)$ \\
\hline C15-H15 & 0.9500 & $\mathrm{C} 25-\mathrm{H} 25$ & 0.9500 \\
\hline $\mathrm{C} 16-\mathrm{N} 17$ & $1.3997(18)$ & $\mathrm{C} 26-\mathrm{N} 27$ & $1.4018(17)$ \\
\hline $\mathrm{C} 16-\mathrm{C} 161$ & $1.4727(19)$ & $\mathrm{C} 26-\mathrm{C} 261$ & $1.470(2)$ \\
\hline N17-C17A & $1.3093(19)$ & $\mathrm{N} 27-\mathrm{C} 27 \mathrm{~A}$ & $1.3087(19)$ \\
\hline $\mathrm{C} 161-\mathrm{C} 162$ & $1.399(2)$ & $\mathrm{C} 261-\mathrm{C} 266$ & $1.400(2)$ \\
\hline C161-C166 & $1.402(2)$ & C261-C262 & $1.4003(19)$ \\
\hline $\mathrm{C} 162-\mathrm{C} 163$ & $1.388(2)$ & $\mathrm{C} 262-\mathrm{C} 263$ & $1.384(2)$ \\
\hline $\mathrm{C} 162-\mathrm{C} 112$ & $1.7441(15)$ & $\mathrm{C} 262-\mathrm{Cl} 22$ & $1.7427(16)$ \\
\hline $\mathrm{C} 163-\mathrm{C} 164$ & $1.380(2)$ & $\mathrm{C} 263-\mathrm{C} 264$ & $1.378(3)$ \\
\hline $\mathrm{C} 163-\mathrm{H} 163$ & 0.9500 & $\mathrm{C} 263-\mathrm{H} 263$ & 0.9500 \\
\hline $\mathrm{C} 164-\mathrm{C} 165$ & $1.381(2)$ & $\mathrm{C} 264-\mathrm{C} 265$ & $1.385(2)$ \\
\hline C164-H164 & 0.9500 & $\mathrm{C} 264-\mathrm{H} 264$ & 0.9500 \\
\hline $\mathrm{C} 165-\mathrm{C} 166$ & $1.381(2)$ & $\mathrm{C} 265-\mathrm{C} 266$ & $1.381(2)$ \\
\hline $\mathrm{C} 165-\mathrm{H} 165$ & 0.9500 & $\mathrm{C} 265-\mathrm{H} 265$ & 0.9500 \\
\hline C166-H166 & 0.9500 & $\mathrm{C} 266-\mathrm{H} 266$ & 0.9500 \\
\hline $\mathrm{C} 17 \mathrm{~A}-\mathrm{S} 11-\mathrm{C} 12$ & $87.72(7)$ & $\mathrm{C} 27 \mathrm{~A}-\mathrm{S} 21-\mathrm{C} 22$ & $87.38(7)$ \\
\hline $\mathrm{N} 13-\mathrm{C} 12-\mathrm{S} 11$ & $117.55(12)$ & $\mathrm{N} 23-\mathrm{C} 22-\mathrm{S} 21$ & $118.02(12)$ \\
\hline $\mathrm{N} 13-\mathrm{C} 12-\mathrm{H} 12$ & 121.2 & $\mathrm{~N} 23-\mathrm{C} 22-\mathrm{H} 22$ & 121.0 \\
\hline $\mathrm{S} 11-\mathrm{C} 12-\mathrm{H} 12$ & 121.2 & $\mathrm{~S} 21-\mathrm{C} 22-\mathrm{H} 22$ & 121.0 \\
\hline C12-N13-N14 & $107.55(12)$ & $\mathrm{C} 22-\mathrm{N} 23-\mathrm{N} 24$ & $107.25(12)$ \\
\hline $\mathrm{C} 17 \mathrm{~A}-\mathrm{N} 14-\mathrm{C} 15$ & $108.02(12)$ & $\mathrm{C} 27 \mathrm{~A}-\mathrm{N} 24-\mathrm{N} 23$ & $118.36(12)$ \\
\hline $\mathrm{C} 17 \mathrm{~A}-\mathrm{N} 14-\mathrm{N} 13$ & $118.43(12)$ & $\mathrm{C} 27 \mathrm{~A}-\mathrm{N} 24-\mathrm{C} 25$ & $107.97(12)$ \\
\hline $\mathrm{C} 15-\mathrm{N} 14-\mathrm{N} 13$ & $133.54(12)$ & $\mathrm{N} 23-\mathrm{N} 24-\mathrm{C} 25$ & $133.63(12)$ \\
\hline $\mathrm{N} 14-\mathrm{C} 15-\mathrm{C} 16$ & $104.46(12)$ & $\mathrm{N} 24-\mathrm{C} 25-\mathrm{C} 26$ & $104.32(12)$ \\
\hline $\mathrm{N} 14-\mathrm{C} 15-\mathrm{H} 15$ & 127.8 & $\mathrm{~N} 24-\mathrm{C} 25-\mathrm{H} 25$ & 127.8 \\
\hline $\mathrm{C} 16-\mathrm{C} 15-\mathrm{H} 15$ & 127.8 & $\mathrm{C} 26-\mathrm{C} 25-\mathrm{H} 25$ & 127.8 \\
\hline $\mathrm{C} 15-\mathrm{C} 16-\mathrm{N} 17$ & $110.91(12)$ & $\mathrm{C} 25-\mathrm{C} 26-\mathrm{N} 27$ & $111.03(12)$ \\
\hline $\mathrm{C} 15-\mathrm{C} 16-\mathrm{C} 161$ & $131.26(13)$ & $\mathrm{C} 25-\mathrm{C} 26-\mathrm{C} 261$ & $131.46(13)$ \\
\hline $\mathrm{N} 17-\mathrm{C} 16-\mathrm{C} 161$ & $117.82(12)$ & $\mathrm{N} 27-\mathrm{C} 26-\mathrm{C} 261$ & $117.51(12)$ \\
\hline $\mathrm{C} 17 \mathrm{~A}-\mathrm{N} 17-\mathrm{C} 16$ & $103.95(12)$ & $\mathrm{C} 27 \mathrm{~A}-\mathrm{N} 27-\mathrm{C} 26$ & $103.84(12)$ \\
\hline $\mathrm{N} 17-\mathrm{C} 17 \mathrm{~A}-\mathrm{N} 14$ & $112.65(13)$ & $\mathrm{N} 27-\mathrm{C} 27 \mathrm{~A}-\mathrm{N} 24$ & $112.83(12)$ \\
\hline N17-C17A-S11 & $138.59(11)$ & $\mathrm{N} 27-\mathrm{C} 27 \mathrm{~A}-\mathrm{S} 21$ & $138.21(11)$ \\
\hline $\mathrm{N} 14-\mathrm{C} 17 \mathrm{~A}-\mathrm{S} 11$ & $108.76(10)$ & $\mathrm{N} 24-\mathrm{C} 27 \mathrm{~A}-\mathrm{S} 21$ & $108.96(10)$ \\
\hline $\mathrm{C} 162-\mathrm{C} 161-\mathrm{C} 166$ & $115.90(13)$ & $\mathrm{C} 266-\mathrm{C} 261-\mathrm{C} 262$ & $116.06(13)$ \\
\hline $\mathrm{C} 162-\mathrm{C} 161-\mathrm{C} 16$ & $126.07(13)$ & $\mathrm{C} 266-\mathrm{C} 261-\mathrm{C} 26$ & $117.91(13)$ \\
\hline $\mathrm{C} 166-\mathrm{C} 161-\mathrm{C} 16$ & $118.03(13)$ & $\mathrm{C} 262-\mathrm{C} 261-\mathrm{C} 26$ & $126.03(13)$ \\
\hline $\mathrm{C} 163-\mathrm{C} 162-\mathrm{C} 161$ & $122.07(14)$ & $\mathrm{C} 263-\mathrm{C} 262-\mathrm{C} 261$ & $122.42(14)$ \\
\hline $\mathrm{C} 163-\mathrm{C} 162-\mathrm{Cl12}$ & $115.91(11)$ & $\mathrm{C} 263-\mathrm{C} 262-\mathrm{Cl} 22$ & $116.03(12)$ \\
\hline $\mathrm{C} 161-\mathrm{C} 162-\mathrm{C} 112$ & $122.00(11)$ & $\mathrm{C} 261-\mathrm{C} 262-\mathrm{C} 222$ & $121.54(12)$ \\
\hline $\mathrm{C} 164-\mathrm{C} 163-\mathrm{C} 162$ & $120.23(15)$ & $\mathrm{C} 264-\mathrm{C} 263-\mathrm{C} 262$ & $119.66(15)$ \\
\hline $\mathrm{C} 164-\mathrm{C} 163-\mathrm{H} 163$ & 119.9 & $\mathrm{C} 264-\mathrm{C} 263-\mathrm{H} 263$ & 120.2 \\
\hline $\mathrm{C} 162-\mathrm{C} 163-\mathrm{H} 163$ & 119.9 & $\mathrm{C} 262-\mathrm{C} 263-\mathrm{H} 263$ & 120.2 \\
\hline $\mathrm{C} 163-\mathrm{C} 164-\mathrm{C} 165$ & $119.19(15)$ & $\mathrm{C} 263-\mathrm{C} 264-\mathrm{C} 265$ & $119.79(15)$ \\
\hline $\mathrm{C} 163-\mathrm{C} 164-\mathrm{H} 164$ & 120.4 & $\mathrm{C} 263-\mathrm{C} 264-\mathrm{H} 264$ & 120.1 \\
\hline
\end{tabular}


supporting information

$\begin{array}{ll}\text { C165-C164-H164 } & 120.4 \\ \text { C166-C165-C164 } & 120.26(16) \\ \text { C166-C165-H165 } & 119.9 \\ \text { C164-C165-H165 } & 119.9 \\ \text { C165-C166-C161 } & 122.32(15) \\ \text { C165-C166-H166 } & 118.8 \\ \text { C161-C166-H166 } & 118.8 \\ & \\ \text { C17A-S11-C12-N13 } & -0.16(14) \\ \text { S11-C12-N13-N14 } & 0.07(18) \\ \text { C12-N13-N14-C17A } & 0.10(19) \\ \text { C12-N13-N14-C15 } & -178.82(16) \\ \text { C17A-N14-C15-C16 } & 0.34(16) \\ \text { N13-N14-C15-C16 } & 179.34(15) \\ \text { N14-C15-C16-N17 } & -0.45(16) \\ \text { N14-C15-C16-C161 } & -179.95(14) \\ \text { C15-C16-N17-C17A } & 0.39(16) \\ \text { C161-C16-N17-C17A } & 179.96(12) \\ \text { C16-N17-C17A-N14 } & -0.17(16) \\ \text { C16-N17-C17A-S11 } & -178.84(14) \\ \text { C15-N14-C17A-N17 } & -0.11(17) \\ \text { N13-N14-C17A-N17 } & -179.28(13) \\ \text { C15-N14-C17A-S11 } & 178.96(10) \\ \text { N13-N14-C17A-S11 } & -0.22(16) \\ \text { C12-S11-C17A-N17 } & 178.89(18) \\ \text { C12-S11-C17A-N14 } & 0.19(11) \\ \text { C15-C16-C161-C162 } & 0.3(2) \\ \text { N17-C16-C161-C162 } & -179.15(13) \\ \text { C15-C16-C161-C166 } & -179.44(16) \\ \text { N17-C16-C161-C166 } & 1.10(19) \\ \text { C166-C161-C162-C163 } & -2.0(2) \\ \text { C16-C161-C162-C163 } & 178.20(14) \\ \text { C166-C161-C162-C112 } & 175.99(12) \\ \text { C16-C161-C162-C112 } & -3.8(2) \\ \text { C161-C162-C163-C164 } & 0.9(2) \\ \text { C112-C162-C163-C164 } & -177.25(12) \\ \text { C162-C163-C164-C165 } & 0.9(3) \\ \text { C163-C164-C165-C166 } & -1.3(3) \\ \text { C164-C165-C166-C161 } & 0.1(3) \\ \text { C162-C161-C166-C165 } & 1.5(2) \\ \text { C16-C161-C166-C165 } & -178.67(16) \\ & \\ & \end{array}$

$$
\begin{aligned}
& \mathrm{C} 265-\mathrm{C} 264-\mathrm{H} 264 \\
& \mathrm{C} 266-\mathrm{C} 265-\mathrm{C} 264 \\
& \mathrm{C} 266-\mathrm{C} 265-\mathrm{H} 265 \\
& \mathrm{C} 264-\mathrm{C} 265-\mathrm{H} 265 \\
& \mathrm{C} 265-\mathrm{C} 266-\mathrm{C} 261 \\
& \mathrm{C} 265-\mathrm{C} 266-\mathrm{H} 266 \\
& \mathrm{C} 261-\mathrm{C} 266-\mathrm{H} 266
\end{aligned}
$$

$\mathrm{C} 27 \mathrm{~A}-\mathrm{S} 21-\mathrm{C} 22-\mathrm{N} 23$

$\mathrm{S} 21-\mathrm{C} 22-\mathrm{N} 23-\mathrm{N} 24$

$\mathrm{C} 22-\mathrm{N} 23-\mathrm{N} 24-\mathrm{C} 27 \mathrm{~A}$

$\mathrm{C} 22-\mathrm{N} 23-\mathrm{N} 24-\mathrm{C} 25$

$\mathrm{C} 27 \mathrm{~A}-\mathrm{N} 24-\mathrm{C} 25-\mathrm{C} 26$

$\mathrm{N} 23-\mathrm{N} 24-\mathrm{C} 25-\mathrm{C} 26$

$\mathrm{N} 24-\mathrm{C} 25-\mathrm{C} 26-\mathrm{N} 27$

$\mathrm{N} 24-\mathrm{C} 25-\mathrm{C} 26-\mathrm{C} 261$

$\mathrm{C} 25-\mathrm{C} 26-\mathrm{N} 27-\mathrm{C} 27 \mathrm{~A}$

$\mathrm{C} 261-\mathrm{C} 26-\mathrm{N} 27-\mathrm{C} 27 \mathrm{~A}$

$\mathrm{C} 26-\mathrm{N} 27-\mathrm{C} 27 \mathrm{~A}-\mathrm{N} 24$

$\mathrm{C} 26-\mathrm{N} 27-\mathrm{C} 27 \mathrm{~A}-\mathrm{S} 21$

$\mathrm{N} 23-\mathrm{N} 24-\mathrm{C} 27 \mathrm{~A}-\mathrm{N} 27$

$\mathrm{C} 25-\mathrm{N} 24-\mathrm{C} 27 \mathrm{~A}-\mathrm{N} 27$

$\mathrm{N} 23-\mathrm{N} 24-\mathrm{C} 27 \mathrm{~A}-\mathrm{S} 21$

$\mathrm{C} 25-\mathrm{N} 24-\mathrm{C} 27 \mathrm{~A}-\mathrm{S} 21$

$\mathrm{C} 22-\mathrm{S} 21-\mathrm{C} 27 \mathrm{~A}-\mathrm{N} 27$

$\mathrm{C} 22-\mathrm{S} 21-\mathrm{C} 27 \mathrm{~A}-\mathrm{N} 24$

$\mathrm{C} 25-\mathrm{C} 26-\mathrm{C} 261-\mathrm{C} 266$

$\mathrm{N} 27-\mathrm{C} 26-\mathrm{C} 261-\mathrm{C} 266$

$\mathrm{C} 25-\mathrm{C} 26-\mathrm{C} 261-\mathrm{C} 262$

$\mathrm{N} 27-\mathrm{C} 26-\mathrm{C} 261-\mathrm{C} 262$

$\mathrm{C} 266-\mathrm{C} 261-\mathrm{C} 262-\mathrm{C} 263$

C26-C261-C262-C263

$\mathrm{C} 266-\mathrm{C} 261-\mathrm{C} 262-\mathrm{Cl} 22$

$\mathrm{C} 26-\mathrm{C} 261-\mathrm{C} 262-\mathrm{C} 22$

C261-C262-C263-C264

$\mathrm{C} 122-\mathrm{C} 262-\mathrm{C} 263-\mathrm{C} 264$

C262-C263-C264-C265

$\mathrm{C} 263-\mathrm{C} 264-\mathrm{C} 265-\mathrm{C} 266$

C264-C265-C266-C261

C262-C261-C266-C265

C26-C261-C266-C265
120.1

119.97 (16)

120.0

120.0

122.09 (14)

119.0

119.0

$-1.15(13)$

0.34 (17)

$1.02(18)$

$178.35(15)$

0.35 (16)

$-177.18(14)$

-0.17 (16)

-179.68 (14)

-0.09 (16)

179.50 (12)

0.32 (17)

$179.45(14)$

$177.53(12)$

-0.44 (17)

$-1.86(16)$

$-179.83(10)$

$-177.60(18)$

1.55 (11)

$172.61(15)$

$-6.9(2)$

$-8.0(3)$

$172.46(14)$

0.7 (2)

$-178.66(15)$

179.48 (11)

0.1 (2)

-0.4 (3)

$-179.21(13)$

$0.0(3)$

$0.0(3)$

0.4 (3)

-0.7 (2)

178.69 (14)

Hydrogen-bond geometry $\left(A,{ }^{\circ}\right)$

\begin{tabular}{lllll}
\hline$D-\mathrm{H} \cdots A$ & $D-\mathrm{H}$ & $\mathrm{H} \cdots A$ & $D \cdots A$ & $D-\mathrm{H} \cdots A$ \\
\hline $\mathrm{C} 12-\mathrm{H} 12 \cdots \mathrm{N} 27$ & 0.95 & 2.33 & $3.280(2)$ & 178
\end{tabular}




\begin{tabular}{llllr}
$\mathrm{C} 25-\mathrm{H} 25 \cdots \mathrm{N} 23^{\mathrm{i}}$ & 0.95 & 2.61 & $3.480(2)$ & 153 \\
$\mathrm{C} 263-\mathrm{H} 263 \cdots \mathrm{N} 13^{\text {ii }}$ & 0.95 & 2.51 & $3.456(2)$ & 179 \\
\hline
\end{tabular}

Symmetry codes: (i) $-x,-y+2,-z+1$; (ii) $-x+1,-y+1,-z+1$.

\section{(II) 6-(2-Chlorophenyl)-2-methylimidazo[2,1-b][1,3,4]thiadiazole}

\section{Crystal data}

\section{$\mathrm{C}_{11} \mathrm{H}_{8} \mathrm{ClN}_{3} \mathrm{~S}$}

$M_{r}=249.71$

Orthorhombic, $\mathrm{Pbca}$

$a=7.5567$ (3) $\AA$

$b=11.4589(5) \AA$

$c=24.9006(11) \AA$

$V=2156.18(16) \AA^{3}$

$Z=8$

$F(000)=1024$

\section{Data collection}

\section{Bruker APEXII CCD}

diffractometer

Radiation source: fine-focus sealed tube $\varphi$ and $\omega$ scans

Absorption correction: multi-scan

(SADABS; Sheldrick, 2003)

$T_{\min }=0.773, T_{\max }=0.870$

15450 measured reflections

\section{Refinement}

Refinement on $F^{2}$

Least-squares matrix: full

$R\left[F^{2}>2 \sigma\left(F^{2}\right)\right]=0.032$

$w R\left(F^{2}\right)=0.086$

$S=1.06$

2666 reflections

146 parameters

0 restraints
$D_{\mathrm{x}}=1.538 \mathrm{Mg} \mathrm{m}^{-3}$

Mo $K \alpha$ radiation, $\lambda=0.71073 \AA$

Cell parameters from 2666 reflections

$\theta=3.2-28.3^{\circ}$

$\mu=0.52 \mathrm{~mm}^{-1}$

$T=200 \mathrm{~K}$

Block, colourless

$0.59 \times 0.47 \times 0.27 \mathrm{~mm}$

2666 independent reflections

2356 reflections with $I>2 \sigma(I)$

$R_{\text {int }}=0.015$

$\theta_{\max }=28.3^{\circ}, \theta_{\min }=3.2^{\circ}$

$h=-10 \rightarrow 10$

$k=-11 \rightarrow 15$

$l=-31 \rightarrow 33$

Hydrogen site location: inferred from neighbouring sites

$\mathrm{H}$-atom parameters constrained

$w=1 /\left[\sigma^{2}\left(F_{\mathrm{o}}^{2}\right)+(0.0406 P)^{2}+1.0733 P\right]$

where $P=\left(F_{\mathrm{o}}^{2}+2 F_{\mathrm{c}}{ }^{2}\right) / 3$

$(\Delta / \sigma)_{\max }=0.001$

$\Delta \rho_{\max }=0.31$ e $\AA^{-3}$

$\Delta \rho_{\min }=-0.42$ e $\AA^{-3}$

Special details

Geometry. All e.s.d.'s (except the e.s.d. in the dihedral angle between two 1.s. planes) are estimated using the full covariance matrix. The cell e.s.d.'s are taken into account individually in the estimation of e.s.d.'s in distances, angles and torsion angles; correlations between e.s.d.'s in cell parameters are only used when they are defined by crystal symmetry. An approximate (isotropic) treatment of cell e.s.d.'s is used for estimating e.s.d.'s involving 1.s. planes.

Fractional atomic coordinates and isotropic or equivalent isotropic displacement parameters $\left(\AA^{2}\right)$

\begin{tabular}{lllll}
\hline & $x$ & $y$ & $z$ & $U_{\text {iso }} * / U_{\text {eq }}$ \\
\hline S1 & $0.80106(5)$ & $0.65665(3)$ & $0.45158(2)$ & $0.03626(12)$ \\
C2 & $0.85112(17)$ & $0.51521(13)$ & $0.42998(6)$ & $0.0287(3)$ \\
N3 & $0.81433(16)$ & $0.43078(11)$ & $0.46262(5)$ & $0.0312(3)$ \\
N4 & $0.74098(15)$ & $0.47874(10)$ & $0.50798(4)$ & $0.0262(2)$ \\
C5 & $0.67939(19)$ & $0.43257(12)$ & $0.55510(5)$ & $0.0287(3)$ \\
H5 & 0.6739 & 0.3527 & 0.5652 & $0.034^{*}$ \\
C6 & $0.62709(16)$ & $0.52820(11)$ & $0.58465(5)$ & $0.0243(3)$
\end{tabular}




\begin{tabular}{lllll} 
N7 & $0.65651(16)$ & $0.63161(10)$ & $0.55642(5)$ & $0.0289(2)$ \\
C7A & $0.72392(17)$ & $0.59658(12)$ & $0.51079(5)$ & $0.0266(3)$ \\
C21 & $0.93002(19)$ & $0.49516(15)$ & $0.37581(6)$ & $0.0369(3)$ \\
H21A & 0.8435 & 0.5158 & 0.3481 & $0.055^{*}$ \\
H21B & 0.9626 & 0.4128 & 0.3721 & $0.055^{*}$ \\
H21C & 1.0358 & 0.5438 & 0.3717 & $0.055^{*}$ \\
C61 & $0.54653(16)$ & $0.53729(11)$ & $0.63833(5)$ & $0.0252(3)$ \\
C62 & $0.52735(19)$ & $0.44666(12)$ & $0.67546(5)$ & $0.0297(3)$ \\
C162 & $0.61184(7)$ & $0.30845(4)$ & $0.66226(2)$ & $0.05021(14)$ \\
C63 & $0.4444(2)$ & $0.46260(14)$ & $0.72479(6)$ & $0.0352(3)$ \\
H63 & 0.4322 & 0.3987 & 0.7488 & $0.042^{*}$ \\
C64 & $0.3800(2)$ & $0.57038(15)$ & $0.73882(6)$ & $0.0370(3)$ \\
H64 & 0.3229 & 0.5815 & 0.7724 & $0.044^{*}$ \\
C65 & $0.3993(2)$ & $0.66291(15)$ & $0.70344(6)$ & $0.0359(3)$ \\
H65 & 0.3564 & 0.7380 & 0.7130 & $0.043^{*}$ \\
C66 & $0.48064(19)$ & $0.64626(13)$ & $0.65427(5)$ & $0.0304(3)$ \\
H66 & 0.4922 & 0.7107 & 0.6305 & $0.036^{*}$ \\
\hline
\end{tabular}

Atomic displacement parameters $\left(\AA^{2}\right)$

\begin{tabular}{lllllll}
\hline & $U^{11}$ & $U^{22}$ & $U^{33}$ & $U^{12}$ & $U^{13}$ & $U^{23}$ \\
\hline S1 & $0.0470(2)$ & $0.02767(19)$ & $0.03408(19)$ & $-0.00163(15)$ & $0.01139(15)$ & $0.00237(14)$ \\
C2 & $0.0254(6)$ & $0.0316(7)$ & $0.0291(6)$ & $-0.0011(5)$ & $-0.0019(5)$ & $-0.0043(5)$ \\
N3 & $0.0355(6)$ & $0.0298(6)$ & $0.0285(6)$ & $0.0010(5)$ & $-0.0011(5)$ & $-0.0074(5)$ \\
N4 & $0.0299(5)$ & $0.0221(5)$ & $0.0267(5)$ & $-0.0007(4)$ & $-0.0020(4)$ & $-0.0030(4)$ \\
C5 & $0.0366(7)$ & $0.0222(6)$ & $0.0274(6)$ & $-0.0018(5)$ & $-0.0027(5)$ & $0.0005(5)$ \\
C6 & $0.0243(5)$ & $0.0224(6)$ & $0.0264(6)$ & $-0.0006(5)$ & $-0.0047(5)$ & $0.0007(5)$ \\
N7 & $0.0340(6)$ & $0.0227(5)$ & $0.0300(6)$ & $0.0011(5)$ & $0.0031(5)$ & $0.0010(4)$ \\
C7A & $0.0281(6)$ & $0.0216(6)$ & $0.0300(6)$ & $-0.0012(5)$ & $0.0002(5)$ & $0.0003(5)$ \\
C21 & $0.0320(7)$ & $0.0484(9)$ & $0.0303(7)$ & $-0.0008(7)$ & $0.0018(5)$ & $-0.0077(6)$ \\
C61 & $0.0241(6)$ & $0.0267(6)$ & $0.0247(6)$ & $-0.0022(5)$ & $-0.0056(5)$ & $-0.0009(5)$ \\
C62 & $0.0319(6)$ & $0.0281(7)$ & $0.0292(6)$ & $-0.0018(5)$ & $-0.0037(5)$ & $0.0015(5)$ \\
C162 & $0.0779(3)$ & $0.0297(2)$ & $0.0430(2)$ & $0.01115(19)$ & $0.0113(2)$ & $0.01119(16)$ \\
C63 & $0.0384(7)$ & $0.0400(8)$ & $0.0272(7)$ & $-0.0071(6)$ & $-0.0022(6)$ & $0.0051(6)$ \\
C64 & $0.0359(7)$ & $0.0488(9)$ & $0.0262(7)$ & $-0.0060(7)$ & $0.0005(5)$ & $-0.0053(6)$ \\
C65 & $0.0392(7)$ & $0.0371(8)$ & $0.0315(7)$ & $0.0017(6)$ & $-0.0004(6)$ & $-0.0073(6)$ \\
C66 & $0.0348(7)$ & $0.0285(7)$ & $0.0278(6)$ & $0.0007(6)$ & $-0.0032(5)$ & $-0.0014(5)$ \\
& & & & & & \\
\hline
\end{tabular}

Geometric parameters ( $\left.\AA,{ }^{\circ}\right)$

\begin{tabular}{llll}
\hline $\mathrm{S} 1-\mathrm{C} 7 \mathrm{~A}$ & $1.7283(14)$ & $\mathrm{C} 21-\mathrm{H} 21 \mathrm{~B}$ & 0.9800 \\
$\mathrm{~S} 1-\mathrm{C} 2$ & $1.7491(15)$ & $\mathrm{C} 21-\mathrm{H} 21 \mathrm{C}$ & 0.9800 \\
$\mathrm{C} 2-\mathrm{N} 3$ & $1.2937(19)$ & $\mathrm{C} 61-\mathrm{C} 62$ & $1.3980(19)$ \\
$\mathrm{C} 2-\mathrm{C} 21$ & $1.4927(19)$ & $\mathrm{C} 61-\mathrm{C} 66$ & $1.4016(19)$ \\
$\mathrm{N} 3-\mathrm{N} 4$ & $1.3731(16)$ & $\mathrm{C} 62-\mathrm{C} 63$ & $1.391(2)$ \\
$\mathrm{N} 4-\mathrm{C} 7 \mathrm{~A}$ & $1.3583(17)$ & $\mathrm{C} 62-\mathrm{C} 162$ & $1.7389(15)$ \\
$\mathrm{N} 4-\mathrm{C} 5$ & $1.3686(17)$ & $\mathrm{C} 63-\mathrm{C} 64$ & $1.372(2)$ \\
$\mathrm{C} 5-\mathrm{C} 6$ & $1.3777(19)$ & $\mathrm{C} 63-\mathrm{H} 63$ & 0.9500
\end{tabular}




\begin{tabular}{|c|c|c|c|}
\hline $\mathrm{C} 5-\mathrm{H} 5$ & 0.9500 & $\mathrm{C} 64-\mathrm{C} 65$ & $1.386(2)$ \\
\hline $\mathrm{C} 6-\mathrm{N} 7$ & $1.3957(17)$ & C64-H64 & 0.9500 \\
\hline C6- 661 & $1.4725(18)$ & $\mathrm{C} 65-\mathrm{C} 66$ & $1.383(2)$ \\
\hline N7-C7A & $1.3082(17)$ & C65-H65 & 0.9500 \\
\hline $\mathrm{C} 21-\mathrm{H} 21 \mathrm{~A}$ & 0.9800 & C66-H66 & 0.9500 \\
\hline $\mathrm{C} 7 \mathrm{~A}-\mathrm{S} 1-\mathrm{C} 2$ & $88.06(7)$ & $\mathrm{C} 2-\mathrm{C} 21-\mathrm{H} 21 \mathrm{C}$ & 109.5 \\
\hline $\mathrm{N} 3-\mathrm{C} 2-\mathrm{C} 21$ & $122.58(13)$ & $\mathrm{H} 21 \mathrm{~A}-\mathrm{C} 21-\mathrm{H} 21 \mathrm{C}$ & 109.5 \\
\hline $\mathrm{N} 3-\mathrm{C} 2-\mathrm{S} 1$ & $116.96(11)$ & $\mathrm{H} 21 \mathrm{~B}-\mathrm{C} 21-\mathrm{H} 21 \mathrm{C}$ & 109.5 \\
\hline $\mathrm{C} 21-\mathrm{C} 2-\mathrm{S} 1$ & $120.45(11)$ & $\mathrm{C} 62-\mathrm{C} 61-\mathrm{C} 66$ & $115.96(12)$ \\
\hline $\mathrm{C} 2-\mathrm{N} 3-\mathrm{N} 4$ & $107.71(12)$ & $\mathrm{C} 62-\mathrm{C} 61-\mathrm{C} 6$ & $126.20(12)$ \\
\hline $\mathrm{C} 7 \mathrm{~A}-\mathrm{N} 4-\mathrm{C} 5$ & $107.93(11)$ & $\mathrm{C} 66-\mathrm{C} 61-\mathrm{C} 6$ & $117.84(12)$ \\
\hline $\mathrm{C} 7 \mathrm{~A}-\mathrm{N} 4-\mathrm{N} 3$ & $118.59(11)$ & $\mathrm{C} 63-\mathrm{C} 62-\mathrm{C} 61$ & $122.21(13)$ \\
\hline $\mathrm{C} 5-\mathrm{N} 4-\mathrm{N} 3$ & $133.46(12)$ & $\mathrm{C} 63-\mathrm{C} 62-\mathrm{Cl} 62$ & $116.87(11)$ \\
\hline $\mathrm{N} 4-\mathrm{C} 5-\mathrm{C} 6$ & $104.36(12)$ & $\mathrm{C} 61-\mathrm{C} 62-\mathrm{Cl} 62$ & $120.90(11)$ \\
\hline $\mathrm{N} 4-\mathrm{C} 5-\mathrm{H} 5$ & 127.8 & $\mathrm{C} 64-\mathrm{C} 63-\mathrm{C} 62$ & $120.16(14)$ \\
\hline $\mathrm{C} 6-\mathrm{C} 5-\mathrm{H} 5$ & 127.8 & $\mathrm{C} 64-\mathrm{C} 63-\mathrm{H} 63$ & 119.9 \\
\hline $\mathrm{C} 5-\mathrm{C} 6-\mathrm{N} 7$ & $111.13(12)$ & $\mathrm{C} 62-\mathrm{C} 63-\mathrm{H} 63$ & 119.9 \\
\hline $\mathrm{C} 5-\mathrm{C} 6-\mathrm{C} 61$ & $131.28(12)$ & $\mathrm{C} 63-\mathrm{C} 64-\mathrm{C} 65$ & $119.30(14)$ \\
\hline $\mathrm{N} 7-\mathrm{C} 6-\mathrm{C} 61$ & $117.58(11)$ & C63-C64-H64 & 120.3 \\
\hline $\mathrm{C} 7 \mathrm{~A}-\mathrm{N} 7-\mathrm{C} 6$ & $103.83(11)$ & C65-C64-H64 & 120.3 \\
\hline $\mathrm{N} 7-\mathrm{C} 7 \mathrm{~A}-\mathrm{N} 4$ & $112.74(12)$ & $\mathrm{C} 66-\mathrm{C} 65-\mathrm{C} 64$ & $120.24(15)$ \\
\hline $\mathrm{N} 7-\mathrm{C} 7 \mathrm{~A}-\mathrm{S} 1$ & $138.59(11)$ & $\mathrm{C} 66-\mathrm{C} 65-\mathrm{H} 65$ & 119.9 \\
\hline $\mathrm{N} 4-\mathrm{C} 7 \mathrm{~A}-\mathrm{S} 1$ & $108.67(10)$ & C64-C65-H65 & 119.9 \\
\hline $\mathrm{C} 2-\mathrm{C} 21-\mathrm{H} 21 \mathrm{~A}$ & 109.5 & $\mathrm{C} 65-\mathrm{C} 66-\mathrm{C} 61$ & $122.10(14)$ \\
\hline $\mathrm{C} 2-\mathrm{C} 21-\mathrm{H} 21 \mathrm{~B}$ & 109.5 & $\mathrm{C} 65-\mathrm{C} 66-\mathrm{H} 66$ & 119.0 \\
\hline $\mathrm{H} 21 \mathrm{~A}-\mathrm{C} 21-\mathrm{H} 21 \mathrm{~B}$ & 109.5 & $\mathrm{C} 61-\mathrm{C} 66-\mathrm{H} 66$ & 119.0 \\
\hline $\mathrm{C} 7 \mathrm{~A}-\mathrm{S} 1-\mathrm{C} 2-\mathrm{N} 3$ & $0.40(11)$ & $\mathrm{C} 2-\mathrm{S} 1-\mathrm{C} 7 \mathrm{~A}-\mathrm{N} 7$ & $178.65(16)$ \\
\hline $\mathrm{C} 7 \mathrm{~A}-\mathrm{S} 1-\mathrm{C} 2-\mathrm{C} 21$ & $179.46(12)$ & $\mathrm{C} 2-\mathrm{S} 1-\mathrm{C} 7 \mathrm{~A}-\mathrm{N} 4$ & $-0.86(10)$ \\
\hline $\mathrm{C} 21-\mathrm{C} 2-\mathrm{N} 3-\mathrm{N} 4$ & $-178.84(12)$ & $\mathrm{C} 5-\mathrm{C} 6-\mathrm{C} 61-\mathrm{C} 62$ & $9.8(2)$ \\
\hline $\mathrm{S} 1-\mathrm{C} 2-\mathrm{N} 3-\mathrm{N} 4$ & $0.20(15)$ & $\mathrm{N} 7-\mathrm{C} 6-\mathrm{C} 61-\mathrm{C} 62$ & $-171.26(13)$ \\
\hline $\mathrm{C} 2-\mathrm{N} 3-\mathrm{N} 4-\mathrm{C} 7 \mathrm{~A}$ & $-0.96(16)$ & $\mathrm{C} 5-\mathrm{C} 6-\mathrm{C} 61-\mathrm{C} 66$ & $-169.56(14)$ \\
\hline $\mathrm{C} 2-\mathrm{N} 3-\mathrm{N} 4-\mathrm{C} 5$ & $-179.32(14)$ & N7-C6-C61-C66 & $9.33(17)$ \\
\hline $\mathrm{C} 7 \mathrm{~A}-\mathrm{N} 4-\mathrm{C} 5-\mathrm{C} 6$ & $-0.05(14)$ & $\mathrm{C} 66-\mathrm{C} 61-\mathrm{C} 62-\mathrm{C} 63$ & $1.4(2)$ \\
\hline $\mathrm{N} 3-\mathrm{N} 4-\mathrm{C} 5-\mathrm{C} 6$ & $178.44(13)$ & $\mathrm{C} 6-\mathrm{C} 61-\mathrm{C} 62-\mathrm{C} 63$ & $-178.00(13)$ \\
\hline $\mathrm{N} 4-\mathrm{C} 5-\mathrm{C} 6-\mathrm{N} 7$ & $-0.25(15)$ & $\mathrm{C} 66-\mathrm{C} 61-\mathrm{C} 62-\mathrm{Cl} 62$ & $-177.10(10)$ \\
\hline $\mathrm{N} 4-\mathrm{C} 5-\mathrm{C} 6-\mathrm{C} 61$ & $178.70(13)$ & $\mathrm{C} 6-\mathrm{C} 61-\mathrm{C} 62-\mathrm{Cl} 62$ & 3.49 (19) \\
\hline $\mathrm{C} 5-\mathrm{C} 6-\mathrm{N} 7-\mathrm{C} 7 \mathrm{~A}$ & $0.45(15)$ & $\mathrm{C} 61-\mathrm{C} 62-\mathrm{C} 63-\mathrm{C} 64$ & $-0.9(2)$ \\
\hline $\mathrm{C} 61-\mathrm{C} 6-\mathrm{N} 7-\mathrm{C} 7 \mathrm{~A}$ & $-178.66(11)$ & $\mathrm{C} 162-\mathrm{C} 62-\mathrm{C} 63-\mathrm{C} 64$ & $177.67(12)$ \\
\hline $\mathrm{C} 6-\mathrm{N} 7-\mathrm{C} 7 \mathrm{~A}-\mathrm{N} 4$ & $-0.49(15)$ & $\mathrm{C} 62-\mathrm{C} 63-\mathrm{C} 64-\mathrm{C} 65$ & $-0.2(2)$ \\
\hline $\mathrm{C} 6-\mathrm{N} 7-\mathrm{C} 7 \mathrm{~A}-\mathrm{S} 1$ & $-179.99(13)$ & $\mathrm{C} 63-\mathrm{C} 64-\mathrm{C} 65-\mathrm{C} 66$ & $0.7(2)$ \\
\hline $\mathrm{C} 5-\mathrm{N} 4-\mathrm{C} 7 \mathrm{~A}-\mathrm{N} 7$ & $0.36(16)$ & $\mathrm{C} 64-\mathrm{C} 65-\mathrm{C} 66-\mathrm{C} 61$ & $-0.2(2)$ \\
\hline $\mathrm{N} 3-\mathrm{N} 4-\mathrm{C} 7 \mathrm{~A}-\mathrm{N} 7$ & $-178.40(11)$ & C62-C61-C66-C65 & $-0.9(2)$ \\
\hline $\mathrm{C} 5-\mathrm{N} 4-\mathrm{C} 7 \mathrm{~A}-\mathrm{S} 1$ & $-179.99(9)$ & $\mathrm{C} 6-\mathrm{C} 61-\mathrm{C} 66-\mathrm{C} 65$ & $178.58(13)$ \\
\hline $\mathrm{N} 3-\mathrm{N} 4-\mathrm{C} 7 \mathrm{~A}-\mathrm{S} 1$ & $1.25(15)$ & & \\
\hline
\end{tabular}


Hydrogen-bond geometry $\left(\AA,{ }^{\circ}\right)$

\begin{tabular}{lllll}
\hline$D-\mathrm{H} \cdots A$ & $D-\mathrm{H}$ & $\mathrm{H} \cdots A$ & $D \cdots A$ & $D-\mathrm{H} \cdots A$ \\
\hline $\mathrm{C} 64-\mathrm{H} 64 \cdots C g 1$ & 0.95 & 2.69 & $3.6297(16)$ & 135 \\
\hline
\end{tabular}

\section{(III) 6-(3,4-Dichlorophenyl)imidazo[2,1-b][1,3,4]thiadiazole}

\section{Crystal data}

$\mathrm{C}_{10} \mathrm{H}_{5} \mathrm{Cl}_{2} \mathrm{~N}_{3} \mathrm{~S}$

$M_{r}=270.13$

Triclinic, $P \overline{1}$

$a=5.5186(2) \AA$

$b=7.5194(3) \AA$

$c=12.8406(5) \AA$

$\alpha=102.027(2)^{\circ}$

$\beta=91.293(2)^{\circ}$

$\gamma=98.430(2)^{\circ}$

$V=514.74(3) \AA^{3}$

\section{Data collection}

\section{Bruker APEXII CCD}

diffractometer

Radiation source: fine-focus sealed tube $\varphi$ and $\omega$ scans

Absorption correction: multi-scan

(SADABS; Sheldrick, 2003)

$T_{\min }=0.747, T_{\max }=0.794$

12326 measured reflections

\section{Refinement}

Refinement on $F^{2}$

Least-squares matrix: full

$R\left[F^{2}>2 \sigma\left(F^{2}\right)\right]=0.027$

$w R\left(F^{2}\right)=0.071$

$S=1.12$

2453 reflections

145 parameters

0 restraints
$Z=2$

$F(000)=272$

$D_{\mathrm{x}}=1.743 \mathrm{Mg} \mathrm{m}^{-3}$

Mo $K \alpha$ radiation, $\lambda=0.71073 \AA$

Cell parameters from 2453 reflections

$\theta=1.6-28.3^{\circ}$

$\mu=0.80 \mathrm{~mm}^{-1}$

$T=200 \mathrm{~K}$

Block, colourless

$0.39 \times 0.38 \times 0.30 \mathrm{~mm}$

2453 independent reflections

2254 reflections with $I>2 \sigma(I)$

$R_{\text {int }}=0.017$

$\theta_{\max }=28.3^{\circ}, \theta_{\min }=1.6^{\circ}$

$h=-7 \rightarrow 7$

$k=-10 \rightarrow 9$

$l=-16 \rightarrow 16$

Hydrogen site location: inferred from neighbouring sites

$\mathrm{H}$-atom parameters constrained

$w=1 /\left[\sigma^{2}\left(F_{\mathrm{o}}{ }^{2}\right)+(0.0289 P)^{2}+0.2696 P\right]$

where $P=\left(F_{\mathrm{o}}{ }^{2}+2 F_{\mathrm{c}}{ }^{2}\right) / 3$

$(\Delta / \sigma)_{\max }<0.001$

$\Delta \rho_{\max }=0.36 \mathrm{e} \AA^{-3}$

$\Delta \rho_{\min }=-0.33$ e $\AA^{-3}$

Special details

Geometry. All e.s.d.'s (except the e.s.d. in the dihedral angle between two 1.s. planes) are estimated using the full covariance matrix. The cell e.s.d.'s are taken into account individually in the estimation of e.s.d.'s in distances, angles and torsion angles; correlations between e.s.d.'s in cell parameters are only used when they are defined by crystal symmetry. An approximate (isotropic) treatment of cell e.s.d.'s is used for estimating e.s.d.'s involving 1.s. planes.

Fractional atomic coordinates and isotropic or equivalent isotropic displacement parameters $\left(\AA^{2}\right)$

\begin{tabular}{lllll}
\hline & $x$ & $y$ & $z$ & $U_{\text {iso }} * / U_{\text {eq }}$ \\
\hline S1 & $0.38539(7)$ & $0.23816(5)$ & $0.21457(3)$ & $0.02811(10)$ \\
C2 & $0.6946(3)$ & $0.3233(2)$ & $0.20847(12)$ & $0.0309(3)$ \\
H2 & 0.7601 & 0.3434 & 0.1434 & $0.037^{*}$ \\
N3 & $0.8315(2)$ & $0.35812(19)$ & $0.29503(11)$ & $0.0315(3)$ \\
N4 & $0.6869(2)$ & $0.31365(16)$ & $0.37429(10)$ & $0.0239(2)$
\end{tabular}




$\begin{array}{lllll}\text { C5 } & 0.7299(3) & 0.31705(19) & 0.48029(11) & 0.0246(3) \\ \text { H5 } & 0.8808 & 0.3550 & 0.5215 & 0.029^{*} \\ \text { C6 } & 0.5040(2) & 0.25266(17) & 0.51328(10) & 0.0197(2) \\ \text { N7 } & 0.3244(2) & 0.20853(16) & 0.43029(9) & 0.0227(2) \\ \text { C7A } & 0.4436(2) & 0.24777(18) & 0.34882(11) & 0.0219(3) \\ \text { C61 } & 0.4443(2) & 0.22702(17) & 0.62041(10) & 0.0203(3) \\ \text { C62 } & 0.6141(3) & 0.29729(18) & 0.70661(11) & 0.0230(3) \\ \text { H62 } & 0.7688 & 0.3634 & 0.6962 & 0.028^{*} \\ \text { C63 } & 0.5574(3) & 0.27087(19) & 0.80769(11) & 0.0239(3) \\ \text { C163 } & 0.77020(8) & 0.36636(6) & 0.91302(3) & 0.04046(12) \\ \text { C64 } & 0.3335(3) & 0.17252(19) & 0.82416(11) & 0.0237(3) \\ \text { C164 } & 0.26526(8) & 0.12731(6) & 0.94788(3) & 0.03559(11) \\ \text { C65 } & 0.1627(3) & 0.10504(19) & 0.73917(11) & 0.0261(3) \\ \text { H65 } & 0.0078 & 0.0397 & 0.7501 & 0.031^{*} \\ \text { C66 } & 0.2170(3) & 0.13257(18) & 0.63811(11) & 0.0232(3) \\ \text { H66 } & 0.0982 & 0.0867 & 0.5804 & 0.028^{*}\end{array}$

Atomic displacement parameters $\left(\AA^{2}\right)$

\begin{tabular}{lllllll}
\hline & $U^{11}$ & $U^{22}$ & $U^{33}$ & $U^{12}$ & $U^{13}$ & $U^{23}$ \\
\hline S1 & $0.0326(2)$ & $0.03413(19)$ & $0.01719(17)$ & $0.00065(14)$ & $0.00128(14)$ & $0.00772(13)$ \\
C2 & $0.0342(8)$ & $0.0359(8)$ & $0.0253(7)$ & $0.0052(6)$ & $0.0105(6)$ & $0.0123(6)$ \\
N3 & $0.0285(6)$ & $0.0405(7)$ & $0.0284(7)$ & $0.0018(5)$ & $0.0098(5)$ & $0.0158(5)$ \\
N4 & $0.0220(6)$ & $0.0271(6)$ & $0.0228(6)$ & $0.0002(4)$ & $0.0043(5)$ & $0.0084(4)$ \\
C5 & $0.0225(6)$ & $0.0282(7)$ & $0.0223(7)$ & $-0.0010(5)$ & $-0.0014(5)$ & $0.0076(5)$ \\
C6 & $0.0216(6)$ & $0.0191(6)$ & $0.0176(6)$ & $0.0016(5)$ & $-0.0001(5)$ & $0.0032(4)$ \\
N7 & $0.0228(6)$ & $0.0271(6)$ & $0.0177(5)$ & $0.0009(4)$ & $0.0010(4)$ & $0.0056(4)$ \\
C7A & $0.0231(6)$ & $0.0236(6)$ & $0.0187(6)$ & $0.0021(5)$ & $0.0010(5)$ & $0.0047(5)$ \\
C61 & $0.0239(6)$ & $0.0193(6)$ & $0.0181(6)$ & $0.0044(5)$ & $0.0020(5)$ & $0.0037(4)$ \\
C62 & $0.0220(6)$ & $0.0247(6)$ & $0.0211(6)$ & $0.0024(5)$ & $-0.0001(5)$ & $0.0031(5)$ \\
C63 & $0.0263(7)$ & $0.0273(7)$ & $0.0174(6)$ & $0.0065(5)$ & $-0.0037(5)$ & $0.0023(5)$ \\
C163 & $0.0346(2)$ & $0.0608(3)$ & $0.02111(19)$ & $-0.00011(18)$ & $-0.00828(15)$ & $0.00398(16)$ \\
C64 & $0.0310(7)$ & $0.0255(6)$ & $0.0163(6)$ & $0.0075(5)$ & $0.0030(5)$ & $0.0062(5)$ \\
C164 & $0.0453(2)$ & $0.0452(2)$ & $0.02001(18)$ & $0.00896(17)$ & $0.00597(15)$ & $0.01367(15)$ \\
C65 & $0.0267(7)$ & $0.0268(7)$ & $0.0236(7)$ & $-0.0015(5)$ & $0.0031(6)$ & $0.0067(5)$ \\
C66 & $0.0252(7)$ & $0.0241(6)$ & $0.0183(6)$ & $-0.0003(5)$ & $-0.0010(5)$ & $0.0035(5)$ \\
& & & & & & \\
\hline
\end{tabular}

Geometric parameters $\left(\AA,{ }^{\circ}\right)$

\begin{tabular}{llll}
\hline $\mathrm{S} 1-\mathrm{C} 7 \mathrm{~A}$ & $1.7310(14)$ & $\mathrm{C} 61-\mathrm{C} 62$ & $1.3951(19)$ \\
$\mathrm{S} 1-\mathrm{C} 2$ & $1.7419(16)$ & $\mathrm{C} 61-\mathrm{C} 66$ & $1.3963(19)$ \\
$\mathrm{C} 2-\mathrm{N} 3$ & $1.288(2)$ & $\mathrm{C} 62-\mathrm{C} 63$ & $1.3891(19)$ \\
$\mathrm{C} 2-\mathrm{H} 2$ & 0.9500 & $\mathrm{C} 62-\mathrm{H} 62$ & 0.9500 \\
$\mathrm{~N} 3-\mathrm{N} 4$ & $1.3730(16)$ & $\mathrm{C} 63-\mathrm{C} 64$ & $1.389(2)$ \\
$\mathrm{N} 4-\mathrm{C} 7 \mathrm{~A}$ & $1.3683(18)$ & $\mathrm{C} 63-\mathrm{C} 63$ & $1.7319(14)$ \\
$\mathrm{N} 4-\mathrm{C} 5$ & $1.3706(18)$ & $\mathrm{C} 64-\mathrm{C} 65$ & $1.385(2)$ \\
$\mathrm{C} 5-\mathrm{C} 6$ & $1.3787(18)$ & $\mathrm{C} 64-\mathrm{C} 64$ & $1.7308(13)$ \\
$\mathrm{C} 5-\mathrm{H} 5$ & 0.9500 & $\mathrm{C} 65-\mathrm{C} 66$ & $1.3885(18)$
\end{tabular}




$\begin{array}{ll}\text { C6-N7 } & 1.3918(17) \\ \text { C6-C61 } & 1.4664(18) \\ \text { N7-C7A } & 1.3105(17) \\ & \\ \text { C7A-S1-C2 } & 87.78(7) \\ \text { N3-C2-S1 } & 117.87(11) \\ \text { N3-C2-H2 } & 121.1 \\ \text { S1-C2-H2 } & 121.1 \\ \text { C2-N3-N4 } & 107.53(12) \\ \text { C7A-N4-C5 } & 107.67(11) \\ \text { C7A-N4-N3 } & 118.21(12) \\ \text { C5-N4-N3 } & 134.12(12) \\ \text { N4-C5-C6 } & 104.11(12) \\ \text { N4-C5-H5 } & 127.9 \\ \text { C6-C5-H5 } & 127.9 \\ \text { C5-C6-N7 } & 111.90(12) \\ \text { C5-C6-C61 } & 127.32(13) \\ \text { N7-C6-C61 } & 120.78(12) \\ \text { C7A-N7-C6 } & 103.47(11) \\ \text { N7-C7A-N4 } & 112.85(12) \\ \text { N7-C7A-S1 } & 138.53(11) \\ \text { N4-C7A-S1 } & 108.61(10) \\ \text { C7A-S1-C2-N3 } & -0.49(13) \\ \text { S1-C2-N3-N4 } & 0.68(17) \\ \text { C2-N3-N4-C7A } & -0.59(18) \\ \text { C2-N3-N4-C5 } & 178.33(15) \\ \text { C7A-N4-C5-C6 } & -0.43(15) \\ \text { N3-N4-C5-C6 } & -179.44(14) \\ \text { N4-C5-C6-N7 } & 0.50(15) \\ \text { N4-C5-C6-C61 } & 179.70(12) \\ \text { C5-C6-N7-C7A } & -0.36(15) \\ \text { C61-C6-N7-C7A } & -179.62(12) \\ \text { C6-N7-C7A-N4 } & 0.07(15) \\ \text { C6-N7-C7A-S1 } & 178.89(13) \\ \text { C5-N4-C7A-N7 } & 0.24(16) \\ \text { N3-N4-C7A-N7 } & 179.43(12) \\ \text { C5-N4-C7A-S1 } & -178.94(9) \\ \text { N3-N4-C7A-S1 } & 0.25(15) \\ \text { C2-S1-C7A-N7 } & -178.75(17) \\ \text { C2-S1-C7A-N4 } & 0.11(10) \\ & \end{array}$

C65-H65

C66-H66

C62-C61-C66

C62-C61-C6

$\mathrm{C} 66-\mathrm{C} 61-\mathrm{C} 6$

C63-C62-C61

$\mathrm{C} 63-\mathrm{C} 62-\mathrm{H} 62$

C61- $62-\mathrm{H} 62$

$\mathrm{C} 64-\mathrm{C} 63-\mathrm{C} 62$

$\mathrm{C} 64-\mathrm{C} 63-\mathrm{Cl} 63$

C62-C63-Cl63

C65-C64-C63

C65-C64- $\mathrm{Cl} 64$

C63-C64-Cl64

$\mathrm{C} 64-\mathrm{C} 65-\mathrm{C} 66$

C64-C65-H65

C66- C65-H65

C65-C66-C61

C65-C66-H66

C61-C66-H66

C5-C6-C61-C62

N7-C6-C61-C62

C5-C6-C61- 666

N7-C6-C61-C66

C66-C61-C62-C63

C6- C61-C62-C63

C61-C62-C63-C64

C61-C62-C63-C163

C62-C63-C64- 655

$\mathrm{C} 163-\mathrm{C} 63-\mathrm{C} 64-\mathrm{C} 65$

C62-C63-C64-Cl64

Cl63-C63-C64-Cl64

C63-C64-C65-C66

Cl64-C64-C65-C66

C64-C65-C66-C61

C62-C61-C66-C65

C6-C61-C66-C65
0.9500

0.9500

$118.83(12)$

$120.44(12)$

$120.73(12)$

$120.16(13)$

119.9

119.9

$120.69(13)$

$120.76(11)$

$118.55(11)$

$119.37(12)$

$119.10(11)$

$121.51(11)$

$120.26(13)$

119.9

119.9

$120.66(13)$

119.7

119.7

$10.8(2)$

$-170.07(12)$

$-169.40(13)$

$9.73(19)$

0.9 (2)

$-179.33(12)$

0.9 (2)

$-178.12(10)$

$-1.9(2)$

$177.06(11)$

$176.50(11)$

$-4.52(17)$

$1.2(2)$

$-177.23(11)$

0.5 (2)

$-1.6(2)$

178.64 (12)

(IV) 6-(4-Fluoro-3-methoxyphenyl)-2-methylimidazo[2,1-b][1,3,4] thiadiazole

Crystal data

$\mathrm{C}_{12} \mathrm{H}_{10} \mathrm{FN}_{3} \mathrm{OS}$

$M_{r}=263.29$

Triclinic, $P \overline{1}$

$$
\begin{aligned}
& a=8.6766(3) \AA \\
& b=11.7888(4) \AA \\
& c=12.5227(4) \AA
\end{aligned}
$$


$\alpha=103.039(2)^{\circ}$

$\beta=95.189(2)^{\circ}$

$\gamma=110.365(2)^{\circ}$

$V=1149.69(7) \AA^{3}$

$Z=4$

$F(000)=544$

$D_{\mathrm{x}}=1.521 \mathrm{Mg} \mathrm{m}^{-3}$

\section{Data collection}

\section{Bruker APEXII CCD}

diffractometer

Radiation source: fine-focus sealed tube $\varphi$ and $\omega$ scans

Absorption correction: multi-scan

(SADABS; Sheldrick, 2003)

$T_{\min }=0.761, T_{\max }=0.957$

19758 measured reflections

\section{Refinement}

Refinement on $F^{2}$

Least-squares matrix: full

$R\left[F^{2}>2 \sigma\left(F^{2}\right)\right]=0.036$

$w R\left(F^{2}\right)=0.105$

$S=1.05$

5695 reflections

329 parameters

0 restraints
Mo $K \alpha$ radiation, $\lambda=0.71073 \AA$

Cell parameters from 5697 reflections

$\theta=2.2-28.4^{\circ}$

$\mu=0.29 \mathrm{~mm}^{-1}$

$T=200 \mathrm{~K}$

Block, colourless

$0.51 \times 0.49 \times 0.16 \mathrm{~mm}$

5695 independent reflections

4829 reflections with $I>2 \sigma(I)$

$R_{\text {int }}=0.019$

$\theta_{\text {max }}=28.4^{\circ}, \theta_{\text {min }}=2.2^{\circ}$

$h=-11 \rightarrow 11$

$k=-15 \rightarrow 15$

$l=-16 \rightarrow 16$

Hydrogen site location: inferred from neighbouring sites

$\mathrm{H}$-atom parameters constrained

$w=1 /\left[\sigma^{2}\left(F_{\mathrm{o}}^{2}\right)+(0.0578 P)^{2}+0.3149 P\right]$

where $P=\left(F_{\mathrm{o}}{ }^{2}+2 F_{\mathrm{c}}{ }^{2}\right) / 3$

$(\Delta / \sigma)_{\max }=0.001$

$\Delta \rho_{\max }=0.38$ e $\AA^{-3}$

$\Delta \rho_{\min }=-0.24$ e $\AA^{-3}$

Special details

Geometry. All e.s.d.'s (except the e.s.d. in the dihedral angle between two 1.s. planes) are estimated using the full covariance matrix. The cell e.s.d.'s are taken into account individually in the estimation of e.s.d.'s in distances, angles and torsion angles; correlations between e.s.d.'s in cell parameters are only used when they are defined by crystal symmetry. An approximate (isotropic) treatment of cell e.s.d.'s is used for estimating e.s.d.'s involving 1.s. planes.

Fractional atomic coordinates and isotropic or equivalent isotropic displacement parameters $\left(\AA^{2}\right)$

\begin{tabular}{lllll}
\hline & $x$ & $y$ & $z$ & $U_{\text {iso }} / U_{\text {eq }}$ \\
\hline S11 & $0.00646(4)$ & $0.13559(3)$ & $0.37155(3)$ & $0.03362(10)$ \\
C12 & $0.08673(17)$ & $0.27326(13)$ & $0.32795(11)$ & $0.0301(3)$ \\
N13 & $0.22531(15)$ & $0.35907(11)$ & $0.38809(9)$ & $0.0308(2)$ \\
N14 & $0.27389(14)$ & $0.31605(11)$ & $0.47316(9)$ & $0.0285(2)$ \\
C15 & $0.40549(18)$ & $0.36681(13)$ & $0.56107(11)$ & $0.0308(3)$ \\
H15 & 0.4947 & 0.4467 & 0.5792 & $0.037^{*}$ \\
C16 & $0.37966(17)$ & $0.27620(13)$ & $0.61728(11)$ & $0.0279(3)$ \\
N17 & $0.23394(15)$ & $0.17076(11)$ & $0.56618(10)$ & $0.0314(3)$ \\
C17A & $0.17615(17)$ & $0.19957(13)$ & $0.48028(11)$ & $0.0285(3)$ \\
C121 & $0.00056(19)$ & $0.28957(15)$ & $0.22791(12)$ & $0.0373(3)$ \\
H12A & 0.0027 & 0.2284 & 0.1611 & $0.056^{*}$ \\
H12B & 0.0578 & 0.3750 & 0.2219 & $0.056^{*}$ \\
H12C & -0.1157 & 0.2761 & 0.2348 & $0.056^{*}$ \\
C161 & $0.48497(17)$ & $0.28344(13)$ & $0.71864(11)$ & $0.0289(3)$ \\
C162 & $0.43884(17)$ & $0.18333(13)$ & $0.76701(11)$ & $0.0289(3)$
\end{tabular}




\begin{tabular}{|c|c|c|c|c|}
\hline H162 & 0.3399 & 0.1112 & 0.7334 & $0.035^{*}$ \\
\hline $\mathrm{C} 163$ & $0.53600(17)$ & $0.18833(14)$ & $0.86345(11)$ & $0.0305(3)$ \\
\hline C164 & $0.68099(18)$ & $0.29526(15)$ & $0.91037(12)$ & $0.0343(3)$ \\
\hline F164 & $0.77811(12)$ & $0.29987(10)$ & $1.00385(8)$ & $0.0463(2)$ \\
\hline $\mathrm{C} 165$ & 0.72848 (19) & $0.39468(15)$ & $0.86428(13)$ & $0.0380(3)$ \\
\hline H165 & 0.8275 & 0.4667 & 0.8982 & $0.046^{*}$ \\
\hline C166 & 0.63049 (19) & $0.38888(14)$ & $0.76772(13)$ & $0.0350(3)$ \\
\hline H166 & 0.6627 & 0.4570 & 0.7350 & $0.042 *$ \\
\hline O163 & $0.50367(13)$ & $0.09665(10)$ & $0.91665(9)$ & $0.0379(2)$ \\
\hline C167 & $0.35126(19)$ & $-0.01095(14)$ & $0.87181(13)$ & $0.0370(3)$ \\
\hline H17A & 0.3504 & -0.0494 & 0.7936 & $0.055^{*}$ \\
\hline H17B & 0.2559 & 0.0152 & 0.8765 & $0.055^{*}$ \\
\hline $\mathrm{H} 17 \mathrm{C}$ & 0.3431 & -0.0722 & 0.9146 & $0.055^{*}$ \\
\hline S21 & $0.78227(5)$ & $0.13419(4)$ & $0.62262(3)$ & $0.03651(11$ \\
\hline $\mathrm{C} 22$ & 0.94908 (17) & $0.27885(14)$ & $0.68237(12)$ & $0.0330(3)$ \\
\hline $\mathrm{N} 23$ & $0.96304(15)$ & $0.36656(12)$ & $0.63253(10)$ & $0.0327(3)$ \\
\hline $\mathrm{N} 24$ & $0.83426(14)$ & $0.31918(11)$ & $0.54278(9)$ & $0.0300(2)$ \\
\hline $\mathrm{C} 25$ & $0.79000(17)$ & $0.36683(13)$ & $0.46012(11)$ & $0.0308(3)$ \\
\hline $\mathrm{H} 25$ & 0.8426 & 0.4488 & 0.4514 & $0.037^{*}$ \\
\hline $\mathrm{C} 26$ & $0.65212(16)$ & $0.26908(13)$ & $0.39250(11)$ & $0.0285(3)$ \\
\hline $\mathrm{N} 27$ & 0.61083 (14) & $0.16220(11)$ & $0.43120(10)$ & $0.0311(3)$ \\
\hline C27A & 0.72405 (17) & $0.19776(13)$ & $0.52154(11)$ & $0.0299(3)$ \\
\hline $\mathrm{C} 221$ & 1.06817 (19) & $0.29945(17)$ & $0.78443(13)$ & $0.0416(4)$ \\
\hline $\mathrm{H} 22 \mathrm{~A}$ & 1.1227 & 0.2388 & 0.7704 & $0.062 *$ \\
\hline $\mathrm{H} 22 \mathrm{~B}$ & 1.0074 & 0.2880 & 0.8459 & $0.062 *$ \\
\hline $\mathrm{H} 22 \mathrm{C}$ & 1.1530 & 0.3852 & 0.8043 & $0.062 *$ \\
\hline C261 & $0.55382(16)$ & $0.27107(13)$ & $0.29205(11)$ & $0.0282(3)$ \\
\hline C262 & $0.40568(16)$ & $0.16877(13)$ & $0.23951(11)$ & $0.0287(3)$ \\
\hline $\mathrm{H} 262$ & 0.3699 & 0.0984 & 0.2691 & $0.034^{*}$ \\
\hline $\mathrm{C} 263$ & $0.31052(17)$ & $0.16897(13)$ & 0.14477 (11) & $0.0301(3)$ \\
\hline C264 & $0.36614(18)$ & $0.27413(14)$ & $0.10393(12)$ & $0.0337(3)$ \\
\hline F264 & $0.27138(12)$ & $0.27444(9)$ & $0.01147(8)$ & $0.0461(2)$ \\
\hline C265 & $0.51152(19)$ & $0.37496(14)$ & $0.15271(12)$ & $0.0349(3)$ \\
\hline $\mathrm{H} 265$ & 0.5468 & 0.4449 & 0.1225 & $0.042 *$ \\
\hline C266 & $0.60700(17)$ & $0.37331(14)$ & $0.24735(12)$ & $0.0327(3)$ \\
\hline H266 & 0.7091 & 0.4423 & 0.2817 & $0.039 *$ \\
\hline O263 & $0.16416(13)$ & $0.07545(10)$ & $0.08734(9)$ & $0.0384(2)$ \\
\hline C267 & 0.11887 (19) & $-0.04054(14)$ & $0.11693(13)$ & $0.0373(3)$ \\
\hline $\mathrm{H} 27 \mathrm{~A}$ & 0.0172 & -0.1029 & 0.0660 & $0.056^{*}$ \\
\hline $\mathrm{H} 27 \mathrm{~B}$ & 0.0982 & -0.0270 & 0.1936 & $0.056^{*}$ \\
\hline $\mathrm{H} 27 \mathrm{C}$ & 0.2101 & -0.0713 & 0.1115 & $0.056^{*}$ \\
\hline
\end{tabular}

Atomic displacement parameters $\left(\AA^{2}\right)$

\begin{tabular}{lllllll}
\hline & $U^{11}$ & $U^{22}$ & $U^{33}$ & $U^{12}$ & $U^{13}$ & $U^{23}$ \\
\hline S11 & $0.03049(18)$ & $0.03356(19)$ & $0.03207(18)$ & $0.00582(14)$ & $0.00091(13)$ & $0.01204(14)$ \\
C12 & $0.0296(6)$ & $0.0333(7)$ & $0.0292(6)$ & $0.0121(6)$ & $0.0071(5)$ & $0.0116(5)$ \\
N13 & $0.0332(6)$ & $0.0335(6)$ & $0.0275(6)$ & $0.0119(5)$ & $0.0038(5)$ & $0.0138(5)$
\end{tabular}




\begin{tabular}{|c|c|c|c|c|c|c|}
\hline N14 & $0.0299(6)$ & $0.0280(6)$ & $0.0279(6)$ & $0.0088(5)$ & $0.0048(4)$ & $0.0119(4)$ \\
\hline $\mathrm{C} 15$ & $0.0310(7)$ & $0.0308(7)$ & $0.0287(6)$ & $0.0086(6)$ & $0.0028(5)$ & $0.0108(5)$ \\
\hline $\mathrm{C} 16$ & $0.0286(6)$ & $0.0301(6)$ & $0.0269(6)$ & $0.0116(5)$ & $0.0058(5)$ & $0.0104(5)$ \\
\hline N17 & $0.0304(6)$ & $0.0322(6)$ & $0.0309(6)$ & $0.0093(5)$ & $0.0040(5)$ & $0.0123(5)$ \\
\hline C17A & $0.0287(6)$ & $0.0288(6)$ & $0.0287(6)$ & $0.0100(5)$ & $0.0064(5)$ & $0.0104(5)$ \\
\hline C121 & $0.0330(7)$ & $0.0450(8)$ & $0.0337(7)$ & $0.0119(6)$ & $0.0018(6)$ & $0.0166(6)$ \\
\hline C161 & $0.0282(6)$ & $0.0333(7)$ & $0.0295(6)$ & $0.0145(6)$ & $0.0069(5)$ & $0.0118(5)$ \\
\hline C162 & $0.0280(6)$ & $0.0328(7)$ & $0.0279(6)$ & $0.0123(5)$ & $0.0039(5)$ & $0.0116(5)$ \\
\hline $\mathrm{C} 163$ & $0.0308(7)$ & $0.0364(7)$ & $0.0293(7)$ & $0.0164(6)$ & $0.0061(5)$ & $0.0124(6)$ \\
\hline C164 & $0.0317(7)$ & $0.0410(8)$ & $0.0300(7)$ & $0.0159(6)$ & $-0.0001(5)$ & $0.0079(6)$ \\
\hline F164 & $0.0418(5)$ & $0.0546(6)$ & 0.0377 (5) & $0.0160(4)$ & -0.0085 & $0.0136(4)$ \\
\hline $\mathrm{C} 165$ & $0.0307(7)$ & $0.0353(7)$ & $0.0406(8)$ & $0.0082(6)$ & $-0.0020(6)$ & $0.0067(6)$ \\
\hline C166 & $0.0334(7)$ & $0.0336(7)$ & $0.0376(7)$ & $0.0109(6)$ & $0.0034(6)$ & $0.0133(6)$ \\
\hline $\mathrm{O} 163$ & $0.0374(6)$ & $0.0410(6)$ & $0.0356(5)$ & $0.0121(5)$ & $-0.0012(4)$ & $0.0190(5)$ \\
\hline $\mathrm{C} 167$ & $0.0365(8)$ & $0.0382(8)$ & $0.0380(8)$ & $0.0121(6)$ & $0.0041(6)$ & $0.0183(6)$ \\
\hline S21 & $0.03315(19)$ & $0.0365(2)$ & $0.03448(19)$ & $0.00513(15)$ & $-0.00028(14)$ & $0.01498(15)$ \\
\hline $\mathrm{C} 22$ & $0.0257(6)$ & $0.0395(7)$ & $0.0295(7)$ & $0.0066(6)$ & $0.0033(5)$ & $0.0110(6)$ \\
\hline $\mathrm{N} 23$ & $0.0264(5)$ & $0.0362(6)$ & $0.0281(6)$ & $0.0055(5)$ & -0.0020 & $0.0080(5)$ \\
\hline $\mathrm{N} 24$ & $0.0252(5)$ & $0.0301(6)$ & $0.0277(6)$ & $0.0042(5)$ & $0.0002(4)$ & $0.0065(4)$ \\
\hline $\mathrm{C} 25$ & $0.0279(6)$ & $0.0306(7)$ & $0.0296(7)$ & $0.0074(5)$ & $0.0005(5)$ & $0.0077(5)$ \\
\hline $\mathrm{C} 26$ & $0.0248(6)$ & $0.0313(7)$ & $0.0274(6)$ & $0.0096(5)$ & $0.0033(5)$ & $0.0067(5)$ \\
\hline $\mathrm{N} 27$ & $0.0269(5)$ & $0.0312(6)$ & $0.0299(6)$ & $0.0061(5)$ & $0.0012(4)$ & $0.0077(5)$ \\
\hline $\mathrm{C} 27 \mathrm{~A}$ & $0.0260(6)$ & $0.0309(7)$ & $0.0285(6)$ & $0.0062(5)$ & $0.0036(5)$ & $0.0076(5)$ \\
\hline $\mathrm{C} 221$ & $0.0321(7)$ & $0.0519(9)$ & $0.0352(8)$ & $0.0074(7)$ & $-0.0020(6)$ & $0.0183(7)$ \\
\hline $\mathrm{C} 261$ & $0.0243(6)$ & $0.0321(7)$ & $0.0266(6)$ & $0.0118(5)$ & $0.0026(5)$ & $0.0044(5)$ \\
\hline C262 & $0.0254(6)$ & $0.0307(7)$ & $0.0288(6)$ & $0.0103(5)$ & $0.0021(5)$ & $0.0073(5)$ \\
\hline $\mathrm{C} 263$ & $0.0269(6)$ & $0.0318(7)$ & $0.0295(6)$ & $0.0122(5)$ & $0.0003(5)$ & $0.0046(5)$ \\
\hline C264 & $0.0321(7)$ & $0.0388(8)$ & $0.0316(7)$ & $0.0158(6)$ & $0.0011(5)$ & $0.0106(6)$ \\
\hline F264 & $0.0432(5)$ & $0.0505(6)$ & $0.0418(5)$ & $0.0130(4)$ & $-0.0072(4)$ & $0.0208(4)$ \\
\hline C265 & $0.0358(7)$ & $0.0352(7)$ & $0.0362(7)$ & $0.0138(6)$ & $0.0054(6)$ & $0.0147(6)$ \\
\hline C266 & $0.0264(6)$ & $0.0318(7)$ & $0.0361(7)$ & $0.0086(6)$ & $0.0019(5)$ & $0.0073(6)$ \\
\hline $\mathrm{O} 263$ & $0.0323(5)$ & $0.0346(5)$ & $0.0404(6)$ & $0.0066(4)$ & $-0.0094(4)$ & $0.0112(4)$ \\
\hline $\mathrm{C} 267$ & $0.0345(7)$ & $0.0304(7)$ & $0.0393(8)$ & $0.0065(6)$ & $-0.0051(6)$ & $0.0088(6)$ \\
\hline
\end{tabular}

Geometric parameters $\left(A,{ }^{\circ}\right)$

\begin{tabular}{llll}
\hline $\mathrm{S} 11-\mathrm{C} 17 \mathrm{~A}$ & $1.7297(14)$ & $\mathrm{S} 21-\mathrm{C} 27 \mathrm{~A}$ & $1.7307(15)$ \\
$\mathrm{S} 11-\mathrm{C} 12$ & $1.7605(14)$ & $\mathrm{S} 21-\mathrm{C} 22$ & $1.7531(15)$ \\
$\mathrm{C} 12-\mathrm{N} 13$ & $1.2970(18)$ & $\mathrm{C} 22-\mathrm{N} 23$ & $1.3004(19)$ \\
$\mathrm{C} 12-\mathrm{C} 121$ & $1.4849(19)$ & $\mathrm{C} 22-\mathrm{C} 221$ & $1.4854(19)$ \\
$\mathrm{N} 13-\mathrm{N} 14$ & $1.3717(15)$ & $\mathrm{N} 23-\mathrm{N} 24$ & $1.3708(15)$ \\
$\mathrm{N} 14-\mathrm{C} 17 \mathrm{~A}$ & $1.3678(18)$ & $\mathrm{N} 24-\mathrm{C} 27 \mathrm{~A}$ & $1.3651(18)$ \\
$\mathrm{N} 14-\mathrm{C} 15$ & $1.3687(17)$ & $\mathrm{N} 24-\mathrm{C} 25$ & $1.3693(18)$ \\
$\mathrm{C} 15-\mathrm{C} 16$ & $1.3740(19)$ & $\mathrm{C} 25-\mathrm{C} 26$ & $1.3759(18)$ \\
$\mathrm{C} 15-\mathrm{H} 15$ & 0.9500 & $\mathrm{C} 25-\mathrm{H} 25$ & 0.9500 \\
$\mathrm{C} 16-\mathrm{N} 17$ & $1.3978(17)$ & $\mathrm{C} 26-\mathrm{N} 27$ & $1.3940(18)$ \\
$\mathrm{C} 16-\mathrm{C} 161$ & $1.4630(18)$ & $\mathrm{C} 26-\mathrm{C} 261$ & $1.4641(18)$ \\
$\mathrm{N} 17-\mathrm{C} 17 \mathrm{~A}$ & $1.3075(18)$ & $\mathrm{N} 27-\mathrm{C} 27 \mathrm{~A}$ & $1.3111(17)$
\end{tabular}




\begin{tabular}{|c|c|c|c|}
\hline $\mathrm{C} 121-\mathrm{H} 12 \mathrm{~A}$ & 0.9800 & $\mathrm{C} 221-\mathrm{H} 22 \mathrm{~A}$ & 0.9800 \\
\hline $\mathrm{C} 121-\mathrm{H} 12 \mathrm{~B}$ & 0.9800 & $\mathrm{C} 221-\mathrm{H} 22 \mathrm{~B}$ & 0.9800 \\
\hline $\mathrm{C} 121-\mathrm{H} 12 \mathrm{C}$ & 0.9800 & $\mathrm{C} 221-\mathrm{H} 22 \mathrm{C}$ & 0.9800 \\
\hline $\mathrm{C} 161-\mathrm{C} 166$ & $1.393(2)$ & $\mathrm{C} 261-\mathrm{C} 266$ & $1.394(2)$ \\
\hline C161-C162 & $1.3991(19)$ & $\mathrm{C} 261-\mathrm{C} 262$ & $1.3963(18)$ \\
\hline $\mathrm{C} 162-\mathrm{C} 163$ & $1.3862(18)$ & $\mathrm{C} 262-\mathrm{C} 263$ & $1.3838(18)$ \\
\hline C162-H162 & 0.9500 & $\mathrm{C} 262-\mathrm{H} 262$ & 0.9500 \\
\hline $\mathrm{C} 163-\mathrm{O} 163$ & $1.3559(17)$ & $\mathrm{C} 263-\mathrm{O} 263$ & $1.3594(16)$ \\
\hline C163-C164 & $1.395(2)$ & C263-C264 & $1.395(2)$ \\
\hline C164-F164 & $1.3581(16)$ & $\mathrm{C} 264-\mathrm{F} 264$ & $1.3595(16)$ \\
\hline C164-C165 & $1.374(2)$ & C264-C265 & $1.366(2)$ \\
\hline $\mathrm{C} 165-\mathrm{C} 166$ & $1.388(2)$ & $\mathrm{C} 265-\mathrm{C} 266$ & $1.3912(19)$ \\
\hline C165-H165 & 0.9500 & $\mathrm{C} 265-\mathrm{H} 265$ & 0.9500 \\
\hline C166-H166 & 0.9500 & $\mathrm{C} 266-\mathrm{H} 266$ & 0.9500 \\
\hline $\mathrm{O} 163-\mathrm{C} 167$ & $1.4318(18)$ & $\mathrm{O} 263-\mathrm{C} 267$ & $1.4291(18)$ \\
\hline C167-H17A & 0.9800 & $\mathrm{C} 267-\mathrm{H} 27 \mathrm{~A}$ & 0.9800 \\
\hline C167-H17B & 0.9800 & $\mathrm{C} 267-\mathrm{H} 27 \mathrm{~B}$ & 0.9800 \\
\hline C167-H17C & 0.9800 & $\mathrm{C} 267-\mathrm{H} 27 \mathrm{C}$ & 0.9800 \\
\hline $\mathrm{C} 17 \mathrm{~A}-\mathrm{S} 11-\mathrm{C} 12$ & $88.62(6)$ & $\mathrm{C} 27 \mathrm{~A}-\mathrm{S} 21-\mathrm{C} 22$ & $88.44(7)$ \\
\hline $\mathrm{N} 13-\mathrm{C} 12-\mathrm{C} 121$ & $122.15(13)$ & $\mathrm{N} 23-\mathrm{C} 22-\mathrm{C} 221$ & $121.98(13)$ \\
\hline $\mathrm{N} 13-\mathrm{C} 12-\mathrm{S} 11$ & $116.10(10)$ & $\mathrm{N} 23-\mathrm{C} 22-\mathrm{S} 21$ & $116.53(11)$ \\
\hline $\mathrm{C} 121-\mathrm{C} 12-\mathrm{S} 11$ & $121.75(11)$ & $\mathrm{C} 221-\mathrm{C} 22-\mathrm{S} 21$ & $121.49(12)$ \\
\hline C12-N13-N14 & $108.29(11)$ & $\mathrm{C} 22-\mathrm{N} 23-\mathrm{N} 24$ & $107.87(12)$ \\
\hline $\mathrm{C} 17 \mathrm{~A}-\mathrm{N} 14-\mathrm{C} 15$ & $107.58(11)$ & $\mathrm{C} 27 \mathrm{~A}-\mathrm{N} 24-\mathrm{C} 25$ & $107.60(11)$ \\
\hline $\mathrm{C} 17 \mathrm{~A}-\mathrm{N} 14-\mathrm{N} 13$ & $118.81(11)$ & $\mathrm{C} 27 \mathrm{~A}-\mathrm{N} 24-\mathrm{N} 23$ & $118.89(12)$ \\
\hline $\mathrm{C} 15-\mathrm{N} 14-\mathrm{N} 13$ & $133.59(12)$ & $\mathrm{C} 25-\mathrm{N} 24-\mathrm{N} 23$ & $133.45(12)$ \\
\hline $\mathrm{N} 14-\mathrm{C} 15-\mathrm{C} 16$ & $104.50(12)$ & $\mathrm{N} 24-\mathrm{C} 25-\mathrm{C} 26$ & $104.29(12)$ \\
\hline $\mathrm{N} 14-\mathrm{C} 15-\mathrm{H} 15$ & 127.8 & $\mathrm{~N} 24-\mathrm{C} 25-\mathrm{H} 25$ & 127.9 \\
\hline $\mathrm{C} 16-\mathrm{C} 15-\mathrm{H} 15$ & 127.8 & $\mathrm{C} 26-\mathrm{C} 25-\mathrm{H} 25$ & 127.9 \\
\hline $\mathrm{C} 15-\mathrm{C} 16-\mathrm{N} 17$ & $111.51(12)$ & $\mathrm{C} 25-\mathrm{C} 26-\mathrm{N} 27$ & $111.80(12)$ \\
\hline $\mathrm{C} 15-\mathrm{C} 16-\mathrm{C} 161$ & $126.78(13)$ & $\mathrm{C} 25-\mathrm{C} 26-\mathrm{C} 261$ & $126.64(13)$ \\
\hline $\mathrm{N} 17-\mathrm{C} 16-\mathrm{C} 161$ & $121.70(12)$ & $\mathrm{N} 27-\mathrm{C} 26-\mathrm{C} 261$ & $121.56(12)$ \\
\hline $\mathrm{C} 17 \mathrm{~A}-\mathrm{N} 17-\mathrm{C} 16$ & $103.55(11)$ & $\mathrm{C} 27 \mathrm{~A}-\mathrm{N} 27-\mathrm{C} 26$ & $103.30(11)$ \\
\hline $\mathrm{N} 17-\mathrm{C} 17 \mathrm{~A}-\mathrm{N} 14$ & $112.86(12)$ & $\mathrm{N} 27-\mathrm{C} 27 \mathrm{~A}-\mathrm{N} 24$ & $113.01(13)$ \\
\hline N17-C17A-S11 & $138.95(11)$ & $\mathrm{N} 27-\mathrm{C} 27 \mathrm{~A}-\mathrm{S} 21$ & $138.68(11)$ \\
\hline $\mathrm{N} 14-\mathrm{C} 17 \mathrm{~A}-\mathrm{S} 11$ & $108.17(10)$ & $\mathrm{N} 24-\mathrm{C} 27 \mathrm{~A}-\mathrm{S} 21$ & $108.27(10)$ \\
\hline $\mathrm{C} 12-\mathrm{C} 121-\mathrm{H} 12 \mathrm{~A}$ & 109.5 & $\mathrm{C} 22-\mathrm{C} 221-\mathrm{H} 22 \mathrm{~A}$ & 109.5 \\
\hline $\mathrm{C} 12-\mathrm{C} 121-\mathrm{H} 12 \mathrm{~B}$ & 109.5 & $\mathrm{C} 22-\mathrm{C} 221-\mathrm{H} 22 \mathrm{~B}$ & 109.5 \\
\hline $\mathrm{H} 12 \mathrm{~A}-\mathrm{C} 121-\mathrm{H} 12 \mathrm{~B}$ & 109.5 & $\mathrm{H} 22 \mathrm{~A}-\mathrm{C} 221-\mathrm{H} 22 \mathrm{~B}$ & 109.5 \\
\hline $\mathrm{C} 12-\mathrm{C} 121-\mathrm{H} 12 \mathrm{C}$ & 109.5 & $\mathrm{C} 22-\mathrm{C} 221-\mathrm{H} 22 \mathrm{C}$ & 109.5 \\
\hline $\mathrm{H} 12 \mathrm{~A}-\mathrm{C} 121-\mathrm{H} 12 \mathrm{C}$ & 109.5 & $\mathrm{H} 22 \mathrm{~A}-\mathrm{C} 221-\mathrm{H} 22 \mathrm{C}$ & 109.5 \\
\hline $\mathrm{H} 12 \mathrm{~B}-\mathrm{C} 121-\mathrm{H} 12 \mathrm{C}$ & 109.5 & $\mathrm{H} 22 \mathrm{~B}-\mathrm{C} 221-\mathrm{H} 22 \mathrm{C}$ & 109.5 \\
\hline $\mathrm{C} 166-\mathrm{C} 161-\mathrm{C} 162$ & $119.56(13)$ & $\mathrm{C} 266-\mathrm{C} 261-\mathrm{C} 262$ & $119.44(12)$ \\
\hline $\mathrm{C} 166-\mathrm{C} 161-\mathrm{C} 16$ & $120.82(13)$ & $\mathrm{C} 266-\mathrm{C} 261-\mathrm{C} 26$ & $120.87(12)$ \\
\hline $\mathrm{C} 162-\mathrm{C} 161-\mathrm{C} 16$ & $119.62(12)$ & $\mathrm{C} 262-\mathrm{C} 261-\mathrm{C} 26$ & $119.68(13)$ \\
\hline $\mathrm{C} 163-\mathrm{C} 162-\mathrm{C} 161$ & $120.69(13)$ & $\mathrm{C} 263-\mathrm{C} 262-\mathrm{C} 261$ & $120.61(13)$ \\
\hline $\mathrm{C} 163-\mathrm{C} 162-\mathrm{H} 162$ & 119.7 & $\mathrm{C} 263-\mathrm{C} 262-\mathrm{H} 262$ & 119.7 \\
\hline
\end{tabular}




$\begin{array}{ll}\text { C161-C162-H162 } & 119.7 \\ \text { O163-C163-C162 } & 125.54(13) \\ \text { O163-C163-C164 } & 116.19(12) \\ \text { C162-C163-C164 } & 118.26(13) \\ \text { F164-C164-C165 } & 119.47(13) \\ \text { F164-C164-C163 } & 118.54(13) \\ \text { C165-C164-C163 } & 121.99(13) \\ \text { C164-C165-C166 } & 119.37(14) \\ \text { C164-C165-H165 } & 120.3 \\ \text { C166-C165-H165 } & 120.3 \\ \text { C165-C166-C161 } & 120.12(14) \\ \text { C165-C166-H166 } & 119.9 \\ \text { C161-C166-H166 } & 119.9 \\ \text { C163-O163-C167 } & 116.49(11) \\ \text { O163-C167-H17A } & 109.5 \\ \text { O163-C167-H17B } & 109.5 \\ \text { H17A-C167-H17B } & 109.5 \\ \text { O163-C167-H17C } & 109.5 \\ \text { H17A-C167-H17C } & 109.5 \\ \text { H17B-C167-H17C } & 109.5 \\ \text { C17A-S11-C12-N13 } & -0.34(12) \\ \text { C17A-S11-C12-C121 } & 179.48(12) \\ \text { C121-C12-N13-N14 } & -179.47(12) \\ \text { S11-C12-N13-N14 } & 0.35(15) \\ \text { C12-N13-N14-C17A } & -0.18(17) \\ \text { C12-N13-N14-C15 } & -178.44(14) \\ \text { C17A-N14-C15-C16 } & 0.19(15) \\ \text { N13-N14-C15-C16 } & 178.59(14) \\ \text { N14-C15-C16-N17 } & -0.42(16) \\ \text { N14-C15-C16-C161 } & -179.80(13) \\ \text { C15-C16-N17-C17A } & 0.47(16) \\ \text { C161-C16-N17-C17A } & 179.89(12) \\ \text { C16-N17-C17A-N14 } & -0.34(15) \\ \text { C16-N17-C17A-S11 } & -178.18(13) \\ \text { C15-N14-C17A-N17 } & 0.10(16) \\ \text { N13-N14-C17A-N17 } & -178.58(11) \\ \text { C15-N14-C17A-S11 } & 178.61(9) \\ \text { N13-N14-C17A-S11 } & -0.07(15) \\ \text { C12-S11-C17A-N17 } & 178.12(17) \\ \text { C12-S11-C17A-N14 } & 0.21(10) \\ \text { C15-C16-C161-C166 } & -1.3(2) \\ \text { N17-C16-C161-C166 } & 179.42(13) \\ \text { C15-C16-C161-C162 } & 178.65(13) \\ \text { N17-C16-C161-C162 } & -0.7(2) \\ \text { C166-C161-C162-C163 } & 0.3(2) \\ \text { C16-C161-C162-C163 } & -179.58(12) \\ \text { C161-C162-C163-O163 } & -179.52(13) \\ & \end{array}$

\begin{tabular}{|c|c|}
\hline $\mathrm{C} 261-\mathrm{C} 262-\mathrm{H} 262$ & 119.7 \\
\hline $\mathrm{O} 263-\mathrm{C} 263-\mathrm{C} 262$ & $125.73(13)$ \\
\hline $\mathrm{O} 263-\mathrm{C} 263-\mathrm{C} 264$ & $116.04(12)$ \\
\hline $\mathrm{C} 262-\mathrm{C} 263-\mathrm{C} 264$ & $118.22(13)$ \\
\hline F264-C264-C265 & $119.48(13)$ \\
\hline F264-C264-C263 & $118.02(13)$ \\
\hline $\mathrm{C} 265-\mathrm{C} 264-\mathrm{C} 263$ & $122.50(13)$ \\
\hline $\mathrm{C} 264-\mathrm{C} 265-\mathrm{C} 266$ & $118.80(14)$ \\
\hline $\mathrm{C} 264-\mathrm{C} 265-\mathrm{H} 265$ & 120.6 \\
\hline $\mathrm{C} 266-\mathrm{C} 265-\mathrm{H} 265$ & 120.6 \\
\hline $\mathrm{C} 265-\mathrm{C} 266-\mathrm{C} 261$ & $120.40(13)$ \\
\hline $\mathrm{C} 265-\mathrm{C} 266-\mathrm{H} 266$ & 119.8 \\
\hline $\mathrm{C} 261-\mathrm{C} 266-\mathrm{H} 266$ & 119.8 \\
\hline $\mathrm{C} 263-\mathrm{O} 263-\mathrm{C} 267$ & $116.68(11)$ \\
\hline $\mathrm{O} 263-\mathrm{C} 267-\mathrm{H} 27 \mathrm{~A}$ & 109.5 \\
\hline $\mathrm{O} 263-\mathrm{C} 267-\mathrm{H} 27 \mathrm{~B}$ & 109.5 \\
\hline $\mathrm{H} 27 \mathrm{~A}-\mathrm{C} 267-\mathrm{H} 27 \mathrm{~B}$ & 109.5 \\
\hline $\mathrm{O} 263-\mathrm{C} 267-\mathrm{H} 27 \mathrm{C}$ & 109.5 \\
\hline $\mathrm{H} 27 \mathrm{~A}-\mathrm{C} 267-\mathrm{H} 27 \mathrm{C}$ & 109.5 \\
\hline $\mathrm{H} 27 \mathrm{~B}-\mathrm{C} 267-\mathrm{H} 27 \mathrm{C}$ & 109.5 \\
\hline $\mathrm{C} 27 \mathrm{~A}-\mathrm{S} 21-\mathrm{C} 22-\mathrm{N} 23$ & $-0.59(13)$ \\
\hline $\mathrm{C} 27 \mathrm{~A}-\mathrm{S} 21-\mathrm{C} 22-\mathrm{C} 221$ & $179.60(13)$ \\
\hline $\mathrm{C} 221-\mathrm{C} 22-\mathrm{N} 23-\mathrm{N} 24$ & $-179.25(13)$ \\
\hline $\mathrm{S} 21-\mathrm{C} 22-\mathrm{N} 23-\mathrm{N} 24$ & $0.94(16)$ \\
\hline $\mathrm{C} 22-\mathrm{N} 23-\mathrm{N} 24-\mathrm{C} 27 \mathrm{~A}$ & $-0.95(18)$ \\
\hline $\mathrm{C} 22-\mathrm{N} 23-\mathrm{N} 24-\mathrm{C} 25$ & $-177.64(15)$ \\
\hline $\mathrm{C} 27 \mathrm{~A}-\mathrm{N} 24-\mathrm{C} 25-\mathrm{C} 26$ & $0.17(15)$ \\
\hline $\mathrm{N} 23-\mathrm{N} 24-\mathrm{C} 25-\mathrm{C} 26$ & $177.13(14)$ \\
\hline $\mathrm{N} 24-\mathrm{C} 25-\mathrm{C} 26-\mathrm{N} 27$ & $-0.27(16)$ \\
\hline $\mathrm{N} 24-\mathrm{C} 25-\mathrm{C} 26-\mathrm{C} 261$ & $178.99(13)$ \\
\hline $\mathrm{C} 25-\mathrm{C} 26-\mathrm{N} 27-\mathrm{C} 27 \mathrm{~A}$ & $0.27(16)$ \\
\hline $\mathrm{C} 261-\mathrm{C} 26-\mathrm{N} 27-\mathrm{C} 27 \mathrm{~A}$ & $-179.04(12)$ \\
\hline $\mathrm{C} 26-\mathrm{N} 27-\mathrm{C} 27 \mathrm{~A}-\mathrm{N} 24$ & $-0.15(16)$ \\
\hline $\mathrm{C} 26-\mathrm{N} 27-\mathrm{C} 27 \mathrm{~A}-\mathrm{S} 21$ & $-177.30(14)$ \\
\hline $\mathrm{C} 25-\mathrm{N} 24-\mathrm{C} 27 \mathrm{~A}-\mathrm{N} 27$ & $-0.01(17)$ \\
\hline $\mathrm{N} 23-\mathrm{N} 24-\mathrm{C} 27 \mathrm{~A}-\mathrm{N} 27$ & $-177.49(12)$ \\
\hline $\mathrm{C} 25-\mathrm{N} 24-\mathrm{C} 27 \mathrm{~A}-\mathrm{S} 21$ & $178.01(9)$ \\
\hline $\mathrm{N} 23-\mathrm{N} 24-\mathrm{C} 27 \mathrm{~A}-\mathrm{S} 21$ & $0.53(16)$ \\
\hline $\mathrm{C} 22-\mathrm{S} 21-\mathrm{C} 27 \mathrm{~A}-\mathrm{N} 27$ & $177.26(17)$ \\
\hline $\mathrm{C} 22-\mathrm{S} 21-\mathrm{C} 27 \mathrm{~A}-\mathrm{N} 24$ & $0.02(11)$ \\
\hline $\mathrm{C} 25-\mathrm{C} 26-\mathrm{C} 261-\mathrm{C} 266$ & $8.0(2)$ \\
\hline $\mathrm{N} 27-\mathrm{C} 26-\mathrm{C} 261-\mathrm{C} 266$ & $-172.79(12)$ \\
\hline $\mathrm{C} 25-\mathrm{C} 26-\mathrm{C} 261-\mathrm{C} 262$ & $-172.64(13)$ \\
\hline $\mathrm{N} 27-\mathrm{C} 26-\mathrm{C} 261-\mathrm{C} 262$ & $6.6(2)$ \\
\hline $\mathrm{C} 266-\mathrm{C} 261-\mathrm{C} 262-\mathrm{C} 263$ & $-0.9(2)$ \\
\hline $\mathrm{C} 26-\mathrm{C} 261-\mathrm{C} 262-\mathrm{C} 263$ & $179.71(12)$ \\
\hline $\mathrm{C} 261-\mathrm{C} 262-\mathrm{C} 263-\mathrm{O} 263$ & $-179.49(13)$ \\
\hline
\end{tabular}




\section{supporting information}

$\begin{array}{llll}\mathrm{C} 161-\mathrm{C} 162-\mathrm{C} 163-\mathrm{C} 164 & -0.4(2) & \mathrm{C} 261-\mathrm{C} 262-\mathrm{C} 263-\mathrm{C} 264 & -0.4(2) \\ \mathrm{O} 163-\mathrm{C} 163-\mathrm{C} 164-\mathrm{F} 164 & 0.3(2) & \mathrm{O} 263-\mathrm{C} 263-\mathrm{C} 264-\mathrm{F} 264 & -0.2(2) \\ \mathrm{C} 162-\mathrm{C} 163-\mathrm{C} 164-\mathrm{F} 164 & -178.97(12) & \mathrm{C} 262-\mathrm{C} 263-\mathrm{C} 264-\mathrm{F} 264 & -179.35(12) \\ \mathrm{O} 163-\mathrm{C} 163-\mathrm{C} 164-\mathrm{C} 165 & 179.67(14) & \mathrm{O} 263-\mathrm{C} 263-\mathrm{C} 264-\mathrm{C} 265 & -179.62(13) \\ \mathrm{C} 162-\mathrm{C} 163-\mathrm{C} 164-\mathrm{C} 165 & 0.4(2) & \mathrm{C} 262-\mathrm{C} 263-\mathrm{C} 264-\mathrm{C} 265 & 1.2(2) \\ \mathrm{F} 164-\mathrm{C} 164-\mathrm{C} 165-\mathrm{C} 166 & 178.95(13) & \mathrm{F} 264-\mathrm{C} 264-\mathrm{C} 265-\mathrm{C} 266 & 179.91(13) \\ \mathrm{C} 163-\mathrm{C} 164-\mathrm{C} 165-\mathrm{C} 166 & -0.4(2) & \mathrm{C} 263-\mathrm{C} 264-\mathrm{C} 265-\mathrm{C} 266 & -0.6(2) \\ \mathrm{C} 164-\mathrm{C} 165-\mathrm{C} 166-\mathrm{C} 161 & 0.4(2) & \mathrm{C} 264-\mathrm{C} 265-\mathrm{C} 266-\mathrm{C} 261 & -0.7(2) \\ \mathrm{C} 162-\mathrm{C} 161-\mathrm{C} 166-\mathrm{C} 165 & -0.3(2) & \mathrm{C} 262-\mathrm{C} 261-\mathrm{C} 266-\mathrm{C} 265 & 1.5(2) \\ \mathrm{C} 16-\mathrm{C} 161-\mathrm{C} 166-\mathrm{C} 165 & 179.57(13) & \mathrm{C} 26-\mathrm{C} 261-\mathrm{C} 266-\mathrm{C} 265 & -179.16(13) \\ \mathrm{C} 162-\mathrm{C} 163-\mathrm{O} 163-\mathrm{C} 167 & -3.5(2) & \mathrm{C} 262-\mathrm{C} 263-\mathrm{O} 263-\mathrm{C} 267 & -10.5(2) \\ \mathrm{C} 164-\mathrm{C} 163-\mathrm{O} 163-\mathrm{C} 167 & 177.32(13) & \mathrm{C} 264-\mathrm{C} 263-\mathrm{O} 263-\mathrm{C} 267 & 170.39(13)\end{array}$

Hydrogen-bond geometry $\left(\AA,{ }^{\circ}\right)$

\begin{tabular}{lllll}
\hline$D-\mathrm{H} \cdots A$ & $D-\mathrm{H}$ & $\mathrm{H} \cdots A$ & $D \cdots A$ & $D-\mathrm{H} \cdots A$ \\
\hline $\mathrm{C} 15-\mathrm{H} 15 \cdots \mathrm{N} 13^{\mathrm{i}}$ & 0.95 & 2.61 & $3.551(2)$ & 169 \\
\hline
\end{tabular}

Symmetry code: (i) $-x+1,-y+1,-z+1$. 